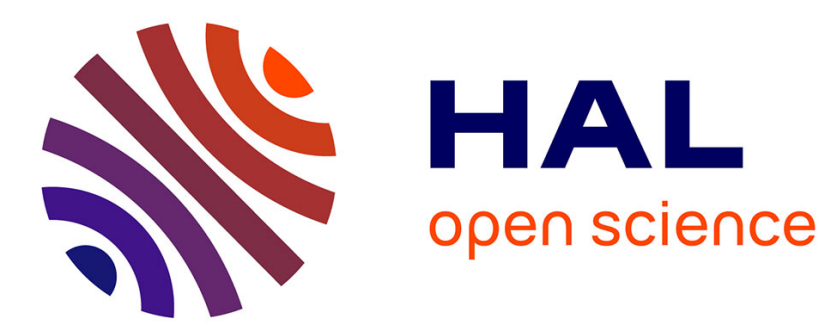

\title{
Compartmentalization of MHC class II gene expression in transgenic mice
}

\author{
Willem van Ewijk, Yacov Ron, John Monaco, John Kappler, Philippa \\ Marrack, Marianne Le Meur, Pierre Gerlinger, Beatrice Claude Durand, \\ Christophe Benoist, Diane Mathis
}

\section{To cite this version:}

Willem van Ewijk, Yacov Ron, John Monaco, John Kappler, Philippa Marrack, et al.. Compartmentalization of MHC class II gene expression in transgenic mice. Cell, 1988, 53 (3), pp.357-370. 10.1016/0092-8674(88)90156-0 . hal-02561158

\section{HAL Id: hal-02561158 \\ https://hal.science/hal-02561158}

Submitted on 24 Nov 2020

HAL is a multi-disciplinary open access archive for the deposit and dissemination of scientific research documents, whether they are published or not. The documents may come from teaching and research institutions in France or abroad, or from public or private research centers.
L'archive ouverte pluridisciplinaire HAL, est destinée au dépôt et à la diffusion de documents scientifiques de niveau recherche, publiés ou non, émanant des établissements d'enseignement et de recherche français ou étrangers, des laboratoires publics ou privés. 


\section{Compartmentalization of MHC Class II Gene Expression in Transgenic Mice}

\author{
Willem van Ewijk,* Yacov Ron, $†$ John Monaco,, \\ John Kappler, $§$ Philippa Marrack, $§$ Marianne Le Meur, ${ }^{\prime \prime}$ \\ Pierre Gerlinger," Beatrice Durand," \\ Christophe Benoist, and Diane Mathis"| \\ *Department of Cell Biology \\ Immunology and Genetics \\ Erasmus University \\ Rotterdam \\ The Netherlands \\ † Department of Immunology \\ Scripps Clinic and Research Foundation \\ La Jolla, California 92037 \\ ¥Department of Microbiology and Immunology \\ Medical College of Virginia \\ Virginia Commonwealth University \\ Richmond, Virginia 23298-0678 \\ $\S$ Howard Hughes Medical Institute \\ National Jewish Center for Immunology and Respiratory \\ Medicine \\ and University of Colorado Health Sciences Center \\ Denver, Colorado 80206 \\ "Laboratoire de Génétique Moléculaire des Eukaryotes \\ du CNRS Unité 184 de Biologie Moléculaire et de \\ Génie Génétique de l'INSERM \\ Faculté de Médecine \\ 11, rue Humann \\ 67085 Strasbourg Cédex \\ France
}

\section{Summary}

A set of transgenic mouse lines carrying $E_{\alpha}^{k}$ genes with promoter region deletions was created in an attempt to compartmentalize MHC class II gene expression. Fine immunohistological analyses established that one transgenic line is essentially devoid of E complex in the thymic cortex, another displays almost no $E$ in the thymic medulla or on peripheral macrophages, and two lines display no $E$ on $>98 \%$ of $B$ cells. We have assayed these mice for immune function: E-dependent tolerance, antigen presentation, $T$ cell priming, and antibody response. Certain of the findings are difficult to reconcile with currently popular hypotheses, e.g., tolerance induction to $\mathrm{E}$ molecules in the virtual absence of $E$ complex in the thymic medulla and efficient antibody responses to E-restricted antigens when almost all $B$ cells are $E^{-}$.

\section{Introduction}

Class II molecules of the major histocompatibility complex $(\mathrm{MHC})$ play a key role in regulating and restricting the immune response (Schwartz, 1984). Two distinct murine class II (or la) complexes have been identified: the A complex, consisting of the $A_{\alpha}$ and $A_{\beta}$ chains; and the $E$ complex, compsed of $E_{\alpha}$ and $E_{\beta}$. The expression of these heterodimeric cell-surface molecules is elaborately controlled, being confined essentially to cells that function in various compartments of the immune system.

In the thymus, la molecules occur on epithelial cells of the cortex, and more abundantly on interdigitating reticular cells and epithelial cells of the medulla. It is in these thymus areas that "education" of T lymphocytes takes place, shaping the repertoire toward recognition of foreign antigens in association with self-MHC (MHC restriction) and away from reactivity against self-MHC alone (MHC tolerance) (Zinkernagel et al., 1978; Fink and Bevan, 1979; Longo and Schwartz, 1980; Singer et al., 1982; Kruisbeek et al., 1984, 1985; Kappler et al., 1987a). The identity and anatomic localization of the thymic cells that impart MHC restriction and $\mathrm{MHC}$ tolerance remain somewhat controversial. Based on reconstitution experiments in nude or irradiated animals, the prevalent view is that the epithelial cells in the cortex dictate MHC restriction, while hematopoetic cells in the medulla are responsible for tolerance induction (Ready et al., 1984; Lo and Sprent, 1986; Von Boehmer and Hafen, 1986; Ron et al., 1986). However, this interpretation is not supported by certain results obtained using murine or avian systems (l.ongo and Davis, 1983; Longo et al., 1985; Jordan et al., 1985; Ohki et al., 1987).

In the periphery, class II molecules occur essentially on $B$ cells and antigen presenting cells (APCs). la expression on $B$ cells has been purported to direct T-B cell collaboration during the antibody response (Sprent, 1978). Expression on APCs is required for MHC-restricted T cell activation. Macrophages ( $M \varphi$ ), interdigitating cells (IDC), and $B$ lymphocytes all express la antigens and each has been shown to be capable of antigen presentation in vitro (Unanue and Allen, 1987; Inaba et al., 1983; Chestnut and Grey, 1981; Kappler et al., 1982; Rock et al., 1984; Malynn and Wortis, 1984; Lanzavecchia, 1985); the relative contribution of these diverse cell types to presentation in vivo has been harder to assess. It does appear that $T$ cell responses are defective in mice rendered B cell-deficient by treatment with anti- $\mu$ antibodies from birth (Ron et al., 1981; Hayglass et al., 1986; Ron and Sprent, 1987, and references therein).

The experimental strategies used to study the role of la molecules in these immunological events have often entailed severe manipulations of the immune system: strong irradiation, in vitro culture of organs in the presence of cytotoxic deoxyguanosine, and depletion of $\mathrm{B}$ cells by multiple anti-immunoglobulin treatments. It would seem valuable to reassess some of the observations under less drastic experimental conditions. Transgenic mice may offer this potential, since the immune system of such animals is manipulated from within (Benoist et al., 1986). We and others have reported the establishment of transgenic lines after the injection of the wild-type $E_{\alpha}$ gene into embryos of genetically $E_{\alpha}$-deficient mice (Le Meur et al. 1985; Yamamura et al., 1985; Pinkert et al., 1985). Expression of the $E_{\alpha}$ transgene in such lines is subject to all anticipated cell-type-specific controls, including responsive- 
ness to inducing agents like gamma-interferon ( $\gamma$-IFN) or interleukin-4 (IL-4). As a consequence, E-restricted immune responses are bestowed on the recipient strain.

By further exploiting the potential offered by transgenic mice, it may be possible to evaluate the role of the $E$ complex in various compartments of the immune system. Our approach has been to preclude expression in specific cell types by injecting $E_{\alpha}$ genes carrying deletions in promoter/enhancer elements. That it is possible to create mutations that influence transcription of $E_{\alpha}$ in a cell-type-specific fashion has already been reported (Dorn et al., 1987; Dorn et al., submitted; Widera et al., 1987). We present here a detailed characterization of $E_{\alpha}$ expression in selected transgenic lines, as well as a multiparameter analysis of the eflect of deficient E complex expression on the operation of the immune system.

\section{Results}

Our transgenic lines derive from C57BI/6 $\times$ SJL (i.e., $B \times$ S) F2 embryos injected with various $E_{a}$ gene fragments. The recipient strain has silent $E_{\alpha}$ genes due to a deletion in the promoter region (Mathis et al., 1983); these mice do, however, synthesize normal $E_{\beta}$. The transgenic animals are maintained as heterozygotes and have been propagated by backcrossing to $\mathrm{C} 57 \mathrm{BI} / 6$ mice for several generations. All experiments include negative littermate controls, i.e., transgene-negative animals from the same litter as the transgenic offspring under examination. We can, then, with some confidence, attribute differences in experimental behavior to the presence or absence of the $\mathrm{E}_{\alpha}^{\mathrm{k}}$ transgene, neglecting the influence of residual genetic material from the original SJL background.

The transgenic strains discussed herein are:

$-E_{\alpha} 16$ and WE32-25: two "wild-type" (WT) transgenic strains that carry approximately ten and five copies, respectively, of a Bgll fragment from the $E_{\alpha}^{k}$ gene (position -2170 to +6800 ). In both these strains, transcription of the $E_{\alpha}^{k}$ transgene is efficient, accurate, and cell-typespecific (Le Meur et al., 1985; Dorn et al., 1987).

- Sma65 and Sma58: two lines obtained by injection of a shorter $E_{\alpha}^{k}$ fragment, spanning positions -1178 to +6800 (Dorn et al., submitted). Transcription is initiated accurately and efficiently in the thymus and in $\gamma$-IFN-induced $M \varphi s$, but the transgenes lack the $-2 \mathrm{~kb}$ to $-1 \mathrm{~kb}$ "B cell control region" and so expression is absent in practically all B cells (Dorn et al., submitted). This phenotype seems similar to that of the $-1.4 \mathrm{~kb} \mathrm{E}_{\alpha}^{\mathrm{d}}\left(\mathrm{V}^{-}\right)$transgenic mice described by Widera et al. (1987).

-WE $\Delta X 21.16$ and $W E \Delta Y 301.54(\Delta X$ and $\Delta Y$ ): lines that carry multiple copies of the -2170 to +6800 Bgll fragment bearing a clean deletion of either the $X$ or $Y$ box-short motifs whose sequence and relative positions are conserved among murine and human class II genes (for references see Dorn et al., 1987). These deletions result in inefficient and aberrantly initiated transcription, although the tissue specificity of expression seems normal. $\gamma$-IFN has no effect on $E_{\alpha}$ expression in macrophages from $\Delta Y$ mice, but does induce $E_{\alpha}$ transcription in $\Delta X$ macrophages. Flow cytometric analysis shows that most $B$ cells are $\mathrm{E}^{+}$in $\Delta \mathrm{X}$ transgenic mice; but that only $20 \%-50 \%$ are $E^{+}$in $\Delta Y$ animals (Dorn et al., 1987).

These analyses at the RNA level demonstrated the influence of diverse sequence elements on the regulation of MHC class II gene expression in different cell types. To further document the differential expression patterns, we undertook a thorough immunohistological investigation.

\section{Thymic Expression}

Serial cryostat sections of thymuses from young transgenic animals were stained with monoclonal antibodies (mAbs) that recognize either the endogenous $A_{0}: A_{\beta}$ or the transgenic $E_{\alpha}: E_{\beta}$ class II complexes; typical thymic sections are shown in Figure 1. In all cases, the anti-A reagent identifies two distinct areas (FIgures $1 \mathrm{~A}, 1 \mathrm{C}, 1 \mathrm{E}$, and $1 G$ ): in the central medullary region ( $m$ ), very strong staining (quasi-confluent) represents MHC class II molecules on interdigitating reticular and medullary epithelial cells; in the cortex (c), staining is more subtle, decorating the fine network of epithelium that radiates from the medulla out to the capsule. The same pattern is seen when an anti$E$ reagent is used to stain thymus sections from the wildtype transgenics WE32.25 and $E_{\alpha} 16$ (Figure $1 B$, and data not shown), a $C 57 \mathrm{BL} / 10 \times \mathrm{A} / \mathrm{J}(\mathrm{B} \times \mathrm{A})$ positive control (data not shown) or the Sma58 and Sma65 transgenic mice (Figure 1D). $\Delta X$ and $\Delta Y$ animals show a strikingly different $E$ complex expression pattern. On $\Delta X$ sections (Figure 1F), there is virtually no staining of the cortex, but the medulla is strongly reactive. A reciprocal image appears on $\Delta Y$ sections (Figure $1 \mathrm{H}$ ): easily detectable $E$ complex on the cortical network, but an essentially blank medulla. There are only a few $\mathrm{E}^{+}$cells in the medullary regions and they are brightly stained.

Double-labeling experiments (data not shown) were performed to establish the identity of the $E^{+}$cells in the $\Delta X$ and $\Delta Y$ thymuses (see Experimental Procedures and van Vliet et al. (1984) for a description of the mAbs). In $\Delta X$ animals, E complex expression in the medulla coincides with the distribution of ER-TR5 and ER-TR6 determinants, indicating that both medullary epithelial cells and IDCs are $\mathrm{E}^{+}$, and establishing that $\Delta \mathrm{X}$ and wild-type medullas are closely resemblant. In $\Delta Y$ animals, there is coincidence of anti-E and ER-TR4 staining in the cortex, the latter reagent being specific for cortical epithelial cells. The rare $\mathrm{E}^{+}$cells in the $\Delta \mathrm{Y}$ medullas are a subset of interdigitating cells, as evidenced by reactivity with ER-TR 6 but not ER-TR5.

To summarize (see Table 1), Sma58 and Sma65 mice seem to exhibit a normal $E$ complex distribution in the thymus, $\Delta X$ animals display an essentially $E^{-}$cortex, the reflection of a defect in $E_{\alpha}$ transgene expression in cortical epithelial cells, and $\Delta Y$ mice show an essentially $E^{-}$ medulla since both the medullary epithelial cells and the IDCs (except for a rare subset) fail to express the $E_{\alpha}$ transgene.

\section{Peripheral Expression}

The complexity of class II gene regulation in peripheral cells is well illustrated by the serial spleen sections from a positive control $B \times A$ animal shown in Figures $2 A$ and 


\section{ANTI-A}
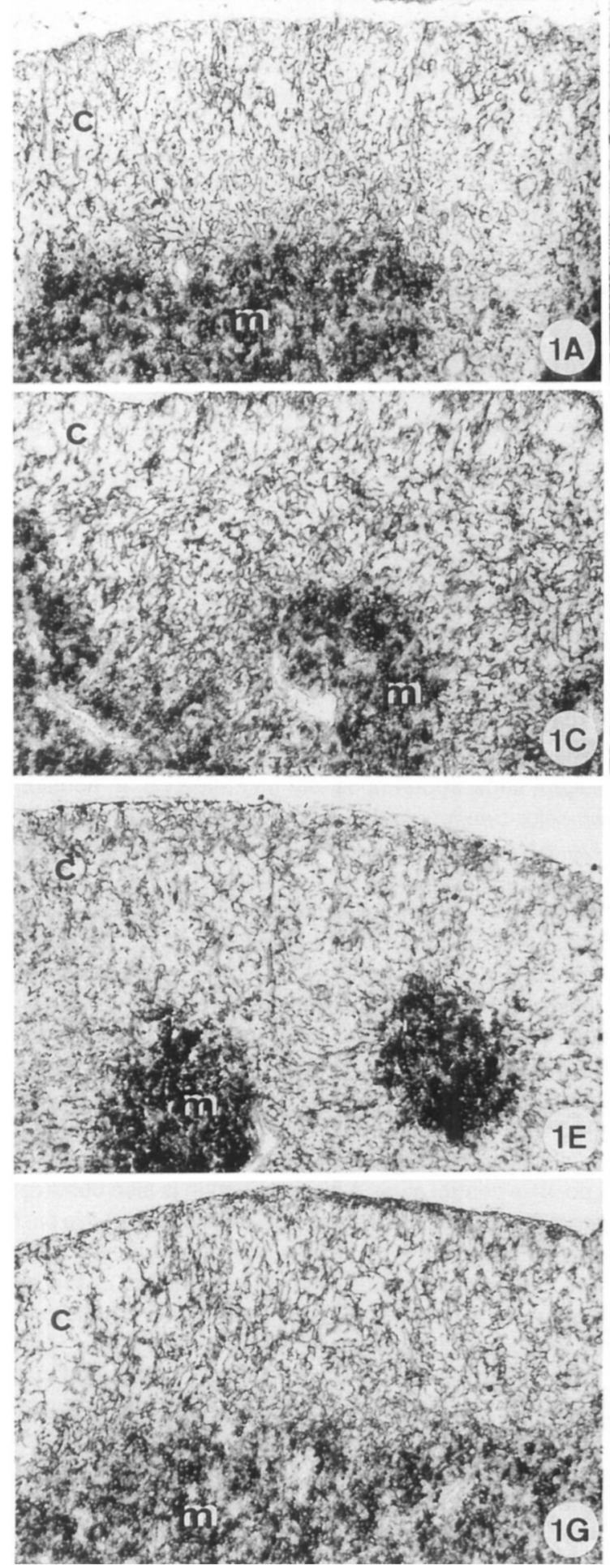

ANTI-E
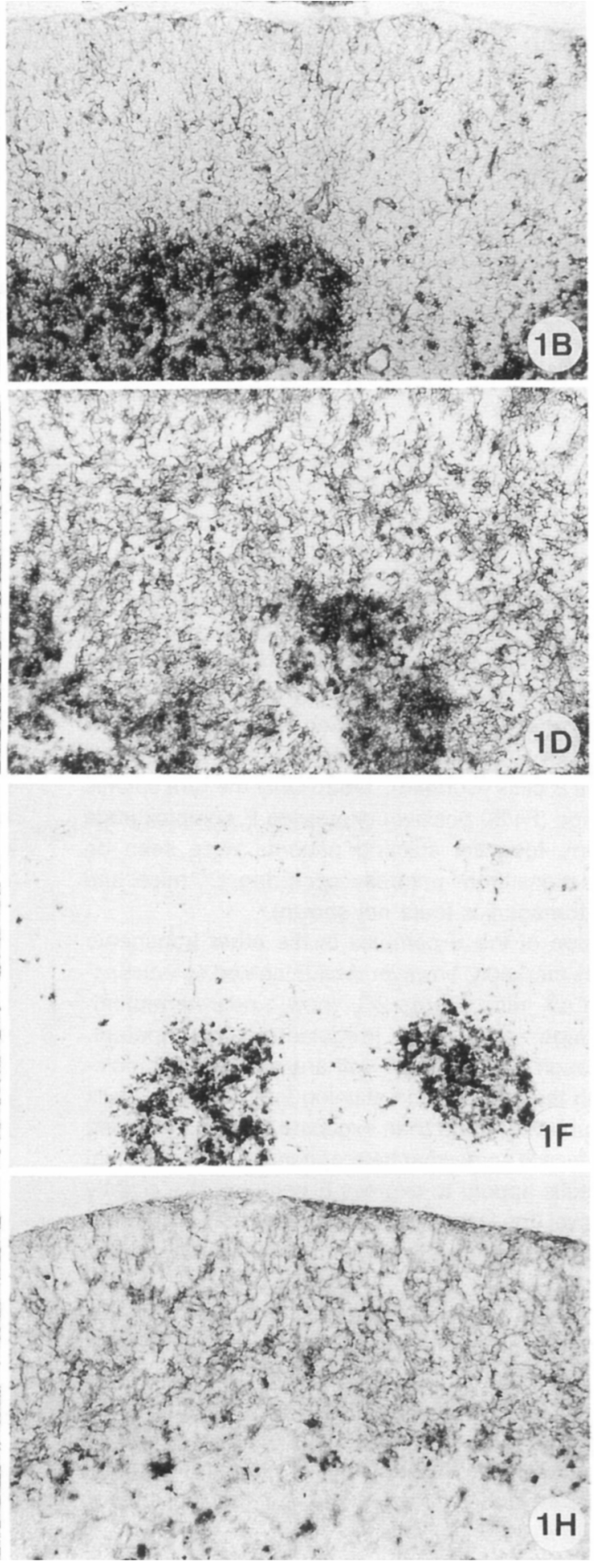

Figure 1. Immunohistology of the Thymus for Various Transgenic Mice

(A-H) represent pairs of adjacent frozen sections, incubated with an anti-A reagent (2A2; $A, C, E$, and $G$ ) or an anti-E reagent (14.4.4 or TR1; B, $D, F$, and H). (A) and (B) show MHC class II molecule expression in "wild-type" transgenic mice; (C) and (D), Sma transgenics; (E) and (F), $\Delta X$ transgenics; $(G)$ and $(H), \Delta Y$ transgenics. (objective: $10 \times) c=$ cortex; $m=$ medulla. 


\begin{tabular}{|c|c|c|c|}
\hline & SMA & $\Delta \mathrm{X}$ & $\Delta Y$ \\
\hline \multicolumn{4}{|l|}{ Thymus } \\
\hline Cortex & Positive & Absent & Positive \\
\hline Medulla & Positive & Positive & $\begin{array}{l}\text { Absent (except for a } \\
\text { few IDC) }\end{array}$ \\
\hline \multicolumn{4}{|l|}{ Periphery } \\
\hline $\begin{array}{l}\text { Folliculat B cells (Sp, } \\
\text { LN; resting) }\end{array}$ & Negalive & $\begin{array}{l}\text { All Positive Bul Some } \\
\text { Heterogeneity }\end{array}$ & $\begin{array}{l}\text { Heterogeneous, ony } \\
20 \%-50 \% \text { of } \mathrm{B} \\
\text { cells are positive }\end{array}$ \\
\hline $\begin{array}{l}\text { Germinal center B cells } \\
\text { (Sp, LN; activated) }\end{array}$ & Positive & Positive (dull) & Heterogeneous \\
\hline T Area IDC (Sp) & Posilive & Positive (low frequency) & Positive (low frequency) \\
\hline Paracortical IDC (LN) & Positive & Positive & Positive (low frequency) \\
\hline Red pulp $M_{\varphi(S p)}$ & Positive ${ }^{a}$ & Positive $^{a}$ & Negative \\
\hline $\begin{array}{l}\text { Peritoned adherent } \\
\text { cells (thioglycollate } \\
\text { elicited }+\gamma \text { - FN } \\
\text { treated) }\end{array}$ & Positive (heterogeneous) & Positive (heterogeneous) & Negative \\
\hline
\end{tabular}

a In normal mice, as well as in WT, Sma, or $\triangle \mathrm{X}$ transgenics, only a fraction of the macrophages identified by staining with the F4/80 mAb are $E^{+}$.

2B. $\mathrm{E}^{+}$cells are found in the red pulp (rp; probably recirculating $B$ cells) and in the $T$ cell areas of the periarteriolar lymphoid sheath ( $p$; clearly IDCs), and there is a homogeneous distribution of anti-E positivity in $B$ cell areas $(f)$. The $B$ cell zones are easily identified in Figure $2 B$ by their reactivity with $R A 3-6 B 2$, an anti-B-220 $\mathrm{mAb}$ that detects virtually all $B$ cells (Coffman, 1982). Only the rare splenic macrophage ( $F 4 / 80$ positive) expresses $E$ complex (data not shown). Identical staining patterns were seen on spleen sections from naturally occurring $\mathrm{E}^{+}$mice and wild-type transgenics (data not shown).

Expression of the $E$ complex in the other transgenic lines varies markedly, however. Anti-E labeled spleen sec. tions from $\Delta X$ mice (Figure $2 \mathrm{C}$ ) show a near-normal image, although some minor irregularities are apparent. First, although IDCs in the $T$ cell areas express $E$ molecules, both the number and staining intensity of $E^{+}$cells appear somewhat lower than expected. Second, staining of $B$ cell areas is somewhat heterogeneous, and germinal center B cells appear to express $E$ complex at a slightly reduced level (the last point is not evident from Figure $2 C$, but is inferred from an examination of other $\Delta X$ and WT slides).

Anti-E labeled $\Lambda Y$ spleen sections (Figure 2E) reveal a more limited expression of the $E$ complex. There is evident, but reduced, $E$ expression in the red pulp, and IDCs in the $T$ cell areas are $\mathrm{E}^{+}$. Some $\Delta \mathrm{Y}$ splenic $\mathrm{B}$ cells clearly express $\mathrm{E}$ complex, but there is a very heterogeneous reactivity. Double-labeling experiments with an anti-E reagent and $F 4 / 80$ demonstrate that no splenic macrophages are $E^{+}$.

Finally, in Sma transgenics, red pulp cells and IDCs in the $T$ cell areas appear normally $E^{+}$(Figure $2 G$ ), but $B$ cell areas do not stain with the anti-E $\mathrm{mAb}$, as anticipated from our previous cytofluorimetric data (compare Figures 2G and 2H; Dorn et al., submitted). We were surm prised, however, to find rather strong staining in the germ:nal centers of these spleens (arrow in Figure 2G), as well as in lymph nodes (asterisk in Figure 21). Several arguments suggest that these $\mathrm{E}^{+}$cells are of the $B$ lymphocyte lineage (data not shown). For example, peanut agglutinin (PNA) selectively stains germinal center $B$ cells (Kraal et al., 1982); serial sections stained with fluorescein isothiocyanate (FITC)-labeled PNA and an FITC-labeled anti-E reagent show superimposable fluorescence. In addition, two-color cytofluorimetric analysis of cells from the mesenteric lymph node reveals that this minor subpopulation is $\mathrm{PNA}^{+}, \mathrm{B}-220^{+}$, slgM ${ }^{-}$.

This immunohistological data and past cytofluorimetric results (Dorn et al., submitted) indicated that $>98 \%$ of $B$ cells are $E^{-}$in Sma transgenics. It was of interest to establish whether E complex molecules could be induced in vitro. Thus, splenocytes from several animals were cultured in the presence of various inducers of class II gene expression, and analyzed by cytofluorimetry $24 \mathrm{hr}$ later (Figure 3). Anti-immunoglobulin (RAMIG) as well as $\|-4$ greatly induce $E$ complex expression on $B$ cells from $B \times$ A positive control mice. A clear induction is also observed with WT, $\Delta X$, or $\Delta Y$ transgenics (data not shown). No such effect is seen with splenocytes from Sma transgenics or $B \times S$ negative controls, although induction of the endogeneous A complex (Figure 3, right panels) attests to the efficacy of the treatment.

To summarize the immunohistological data and past and present cytofiuorimetric findings (Table 1): $\Delta X$ mice show near-normal expression of $E$ complex in the periphery; $\Delta Y$ animals lack $E$ complex on both splenic and peripheral M $\varphi s$, and show marked heterogeneity in $B$ cell expression; Sma mice lack $E$ complex on all B cells expect those residing in germinal centers (i.e., $>98 \%$ ), but show essentially normal expression elsewhere.

\section{Biochemical Characterization of the E Complexes} Clearly, it was important to verify the structural integrity of the transgene-encoded $E_{a}$ molecules; in particular, the aberrantly long transcripts found in $\Delta X$ and $\Delta Y$ cells (Dorn 


\section{ANTI-E ANTI-B220}

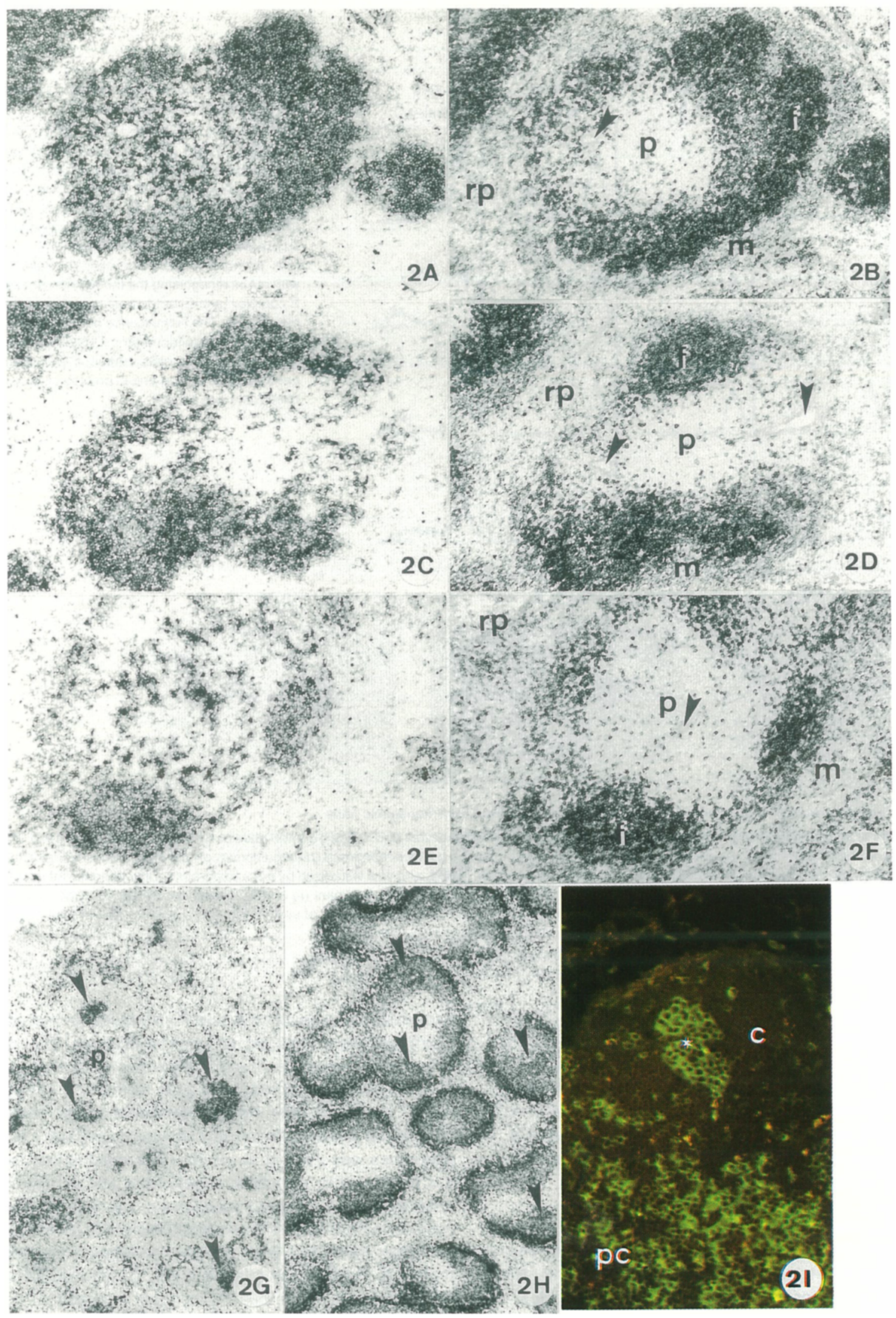

Figure 2. Immunohistology of Peripheral Lymphoid Organs from Various Transgenic Mice

(A-F) represent pairs of adjacent frozen spleen sections. The sections in (A), (C), and (E) were labeied with TR1, and those in (B), (D), and (F) with RA2-6B2, an anti-B220 reagent. $(A)$ and $(B)$ represent the splenic white pulp of $B \times A$ mice; $(C)$ and $(D), \Delta X$ transgenics, $(E)$ and $(F), \Delta Y$ transgenics. The asterisk in (D) indicates a germinal center. $r p=$ red pulp, $m=$ marginal zone, $f=$ follicle, $p=$ periarteriolar lymphoid sheath (T cell zone) Arrows indicate the splenic central arterioles. $(G)$ and $(H)$ show adjacent frozen spleen sections from a Sma transgenic stained with TR1 (G) or RA2 6B2 $(\mathrm{H})$. Germinal centers are indicated by arrows. $\mathrm{p}=$ periarteriolar lymphoid sheath. (I) shows a mesenteric lymph node section from a Sma transgenic, labeled with $14.4 .4 \mathrm{c}=$ corona, $\mathrm{pc}=$ paracortical area, and asterisk $=$ germinal center . 


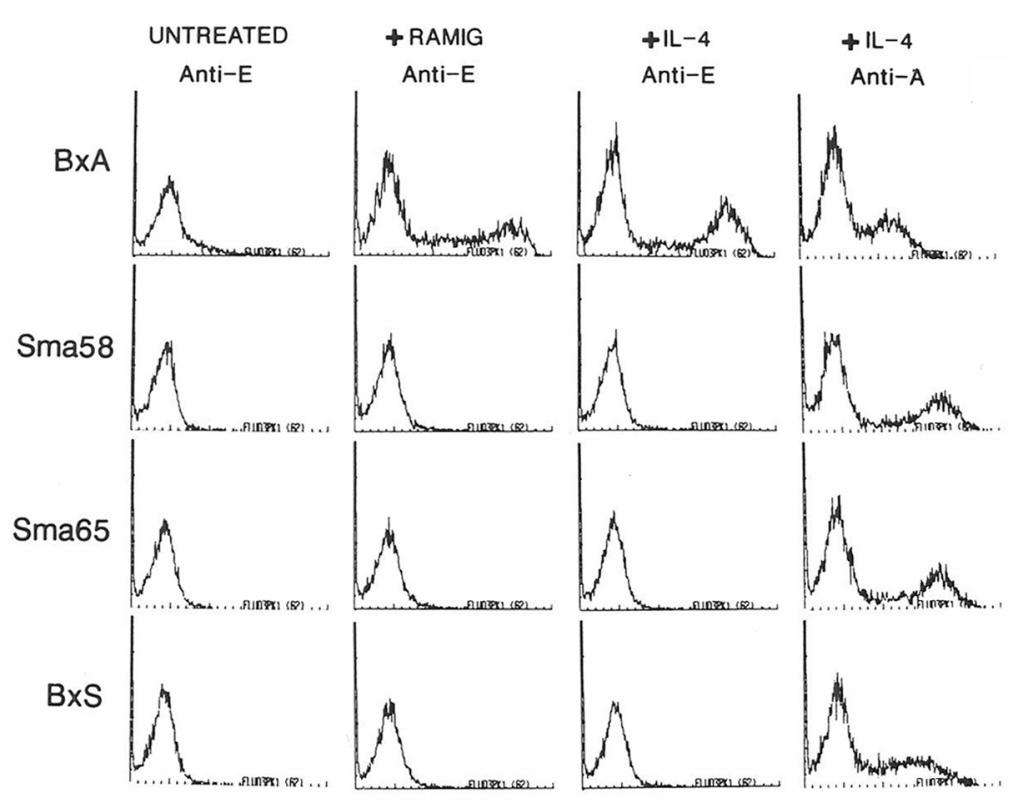

Figure 3. Anti-immunoglobulin and interleukin-4 Treatment of Splenocytes

Cultures were established with spleen cells from $B 10 \times A / J(B \times A)$ positive controls, Sma58 and Sma65 transgenics, and transgene-negative controls $(B \times S)$. IL-4 (a kind gift from $S$. Bergstedt and $E$. Severinson) or affinity-purified rabbit anti-mouse immunoglobulin (RAMIG) were added at the beginning of culture. Twenty-four hours later, cells were slained with mAbs recognizing the transgene-encoded $E$ complex (anti-E) or the host-encoded A complex (anti-A). The fluorescence histograms were obtained by cytofluorimetry. Unstained or irrelevantly stained cells exhibit a profile superimposable on the anti-E profiles of $\mathrm{B} \times \mathrm{S}$ mice (data not shown).

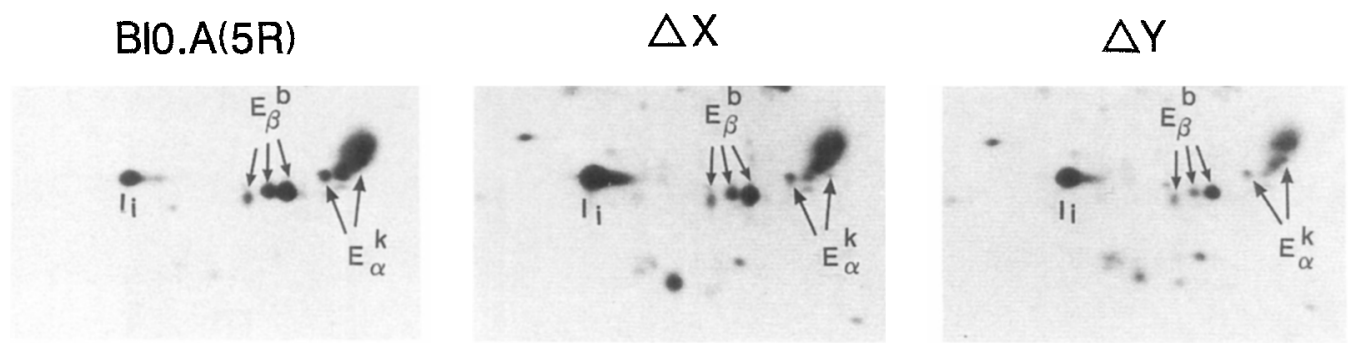

Figure 4. Two-Dimensional Polyacrylamide Gel Analysis of E Complexes from Transgenic Mice

[ ${ }^{35}$ S!methionine labeled $E_{\alpha}: E_{\beta}$ complexes were immunoprecipitated from splenocytes of $B 10 . A(5 R)$ control mice or $\Delta X$ and $\Delta Y$ transgenic mice. The immunoprecipitated material was resolved by two-dimensional polyacrylamide gel electrophoresis (nonequilibrium $\mathrm{pH}$ gel electrofocusing in the first dimension, SDS-polyacrylamide gel electrophoresis in the second [Jones, 1980]), and was visualized hy autoradiography. Only the relevant portion of the autoradiograms is shown. The different $E$ complex components are indicated: the invariant (li) and $E_{\beta}^{b}$ chains are encoded by the genome of the host, while $E_{\alpha}^{k}$ is a product of the transgenes carried in $\Delta X$ and $\Delta Y$ mice. The appearance of several $E_{\alpha}$ and $E_{\beta}$ spots is due to posttranslational modification (glycosylation).

et al., 1987) could translate into abnormal proteins. Thus, splenocytes from each line were radioactively labeled and the $E$ molecules were immunoprecipitated with the 14.4.4 $\mathrm{mAb}$. Figure 4 shows autoradiographs of two-dimensional (NEPHGE/SDS) gels of immunoprecipitated material from $\Delta X, \Delta Y$, and control B10.A(5R) mice. The appearance of the $E_{\beta}^{b}$ and $E_{\alpha}^{k}$ spots are identical in all three cases, indicating the correct size and charge.

\section{Tolerance Induction}

Since expression of MHC class II molecules in the thymus is known to induce tolerance to self-MHC, it was of interest to determine whether this aspect of $\mathrm{T}$ cell education operates efficiently in the transgenic mice that display only partial thymic $E_{\alpha}$ expression. The initial assay was a mixed lymphocyte reaction (MLR; Table 2). Lymph node $T$ cells from various animals were exposed to stimulator spleen cells from either an $E_{\alpha} 16$ transgenic or transgenenegative littermate. The difference in response to the two stimulators reflects perception of the $E$ complex; this difference is tabulated as the $E_{\alpha}^{k}$ stimulation index. In each experiment, responder cells from transgene-negative littermates were included as positive controls. The responses of these cells, from mice obviously not tolerized to the $\mathrm{E}$ complex, reproducibly gave stimulation indices near 2, consistent with the fact that MLRs across single MHC class II molecule barriers are quite inefficient (for references, see Peck et al., 1980). This value is low, but it is reproducible in multiple experiments and cannot be enhanced by any protocol modification we have tried. In contrast to the negative littermates, none of the responder cells from transgenic lines (whether wild-type or mutant) reacted to the $E_{\alpha}^{k}: E_{\beta}^{b}$ complex on the $E_{\alpha} 16$ stimulator cells. Stimulation indices for these responders were about 1 , although they fluctuate somewhat.

$\Lambda$ second, more specific, test of tolerance induction was a determination of the frequency at which the $V_{\beta} 17 a$ variable region occurs on $T$ cell receptors. This variable region occurs predominantly on $T$ cells alloreactive to the $E$ molecule (Kappler et al., 1987b). Because of tolerance induction, mice expressing the $E$ complex have very few mature thymocytes or peripheral $T$ cells that display 


\begin{tabular}{|c|c|c|c|c|c|}
\hline & & & & & \\
\hline \multirow{2}{*}{$\begin{array}{l}\text { Responders } \\
\text { Type }\end{array}$} & \multirow[b]{2}{*}{ Animal Number } & \multicolumn{3}{|c|}{ Stimulators ${ }^{b}$} & \multirow{2}{*}{$\begin{array}{l}\text { E }_{\alpha}^{\mathrm{k}} \text { Stimulation } \\
\text { Index }\end{array}$} \\
\hline & & $E_{0} 16(-)$ & $E_{a} 16(+)$ & $\mathrm{BALB} / \mathrm{C}$ & \\
\hline \multicolumn{6}{|l|}{ Experiment I } \\
\hline \multirow[t]{4}{*}{ Negative littermates } & 1 & 4,310 & 10,390 & 114,380 & 2.40 \\
\hline & 2 & 2,490 & 5,631 & 43,230 & 2.26 \\
\hline & 3 & 8,070 & 17,640 & 172,300 & 2.18 \\
\hline & 4 & 7,460 & 13,220 & 90,040 & 1.77 \\
\hline \multirow[t]{2}{*}{ WT transgenics } & 1 & 7,830 & 8,150 & 131,600 & 1.04 \\
\hline & 2 & 3,320 & 3,300 & 87,140 & 0.99 \\
\hline \multirow[t]{2}{*}{$\Delta \mathrm{X}$ transgenics } & 1 & 6,290 & 4,860 & 84,180 & 0.77 \\
\hline & 2 & 6,700 & 6,050 & 113,650 & 0.90 \\
\hline \multirow[t]{2}{*}{$\Delta Y$ transgenics } & 1 & 4,240 & 5,120 & 67,970 & 1.20 \\
\hline & 2 & 3,180 & 4,270 & 58,840 & 1.34 \\
\hline \multicolumn{6}{|l|}{ Experiment II } \\
\hline \multirow[t]{4}{*}{ Negative littermates } & 1 & 13,350 & 35,030 & 144,400 & 2.62 \\
\hline & 2 & 9,030 & 14,570 & 114,100 & 1.61 \\
\hline & 3 & 21,470 & 42,520 & 112,800 & 1.98 \\
\hline & 4 & 9,420 & 20,960 & 118,930 & 2.22 \\
\hline \multirow[t]{4}{*}{ WT transgenics } & 1 & 2,160 & 3,190 & 68,740 & 1.47 \\
\hline & 2 & 4,110 & 3,140 & 81,150 & 0.76 \\
\hline & 3 & 6,360 & 6,480 & 114,200 & 1.01 \\
\hline & 4 & 12,890 & 12,320 & 139,600 & 0.95 \\
\hline \multirow[t]{3}{*}{$\Delta X$ transgenics } & 1 & 19,600 & 20,330 & 129,200 & 1.03 \\
\hline & 2 & 15,400 & 15,110 & 107,800 & 0.97 \\
\hline & 3 & 5,330 & 7,380 & 97,400 & 1.38 \\
\hline \multirow[t]{2}{*}{$\Delta Y$ transgenics } & 1 & 5,590 & 6,460 & 128,100 & 1.15 \\
\hline & 2 & 7,760 & 9,060 & 107,870 & 1.16 \\
\hline
\end{tabular}

${ }^{a} 2 \times 10^{6}$ lymph node cells pretreated with anti-Lyt2 plus $\mathrm{J11d}+\mathrm{C}^{\prime}$.

${ }^{b} 4 \times 10^{5}$ X-iradiafed spleen cells from an $E_{\alpha} 16$ transgenic $\left(E_{\alpha} 16[+]\right)$, a negative littermale $\left(E_{\alpha} 16[-]\right)$, or BALB/c mouse. Values are cpm of incorporated $\left[{ }^{3} H\right]$ thymidine, and are the average of triplicate determinations. Standard deviation was within $10 \%-20 \%$ of the mean

${ }^{c}$ Reactivity against the $E_{\alpha}^{k}$ transgene product, calculated as the ratio $E_{\alpha} 16(+) / E_{\alpha} 16(-)$.

$V_{\beta} 17 a$, a manifestation of clonal elimination. A greater number of $T$ cells express this receptor in $\mathrm{E}^{-}$mice. (Kappler et al., 1987b). Hence, the mAb KJ23, specific for $V_{\beta} 17 a$, was used to stain peripheral blood lymphocytes from our panel of transgenic mice. The experimental animals actually derive from double backcrosses to SJL mice, a mating that introduces the SJL T cell receptor $\beta$ chain genes (C57BL/6 mice do not carry $V_{\beta}$ 17a genetic information; Kappler et al., 1987a). The results, depicted in Figure 5 , clearly demonstrate clonal elimination of $V_{\beta} 17 a^{+} T$ cells in all of the $E_{\alpha}$ transgenics. The percentages of $\mathrm{KJ}_{2} 3^{+}$peripheral $\mathrm{T}$ cells in SJL mice and negaive littermates are typically about $8 \%-10 \%$, while lower percentages $(1 \%-2 \%)$ are observed with the WT or $\mathrm{SmaE}_{\alpha}$ transgenics (which express the $\mathrm{E}$ complex normally in the thymus) and $\Delta \mathrm{X}$ and $\Delta \mathrm{Y}$ animals (which do not).

Thus, irrespective of their defect in $\mathrm{E}_{\alpha}$ expression, all of the transgenic lines show tolerance to the $\mathrm{E}$ complex, based on both a general assay (MLR) and a specific one (frequency of $V_{\beta} 17 a$ expression).

\section{Antigen Presentation}

We asked whether the cells from transgenic mice exhibiting aberrant peripheral $\mathrm{E}$ complex expression present an- tigen in an E-restricted fashion. The Thybridoma 2B4specific for the 88-103 peptide of moth cytochrome $c$ (MCC) and restricted by the E complex - was cultured with irradiated spleen cells from various animals in the presence of increasing amounts of antigen (Schwartz et al. 1985). Successful MHC-restricted presentation should provoke $2 \mathrm{~B} 4$ to produce interleukin-2, which is then quantitated using IL-2-dependent CTLL indicator cells. The results presented in Figure 6 demonstrate two types of response. First, the dose-response curves for Sma APCs are superimposable on those for APCs from wild-type transgenics or $B 10 . A(5 R)$ mice (WT; Figure $6 A)$. On the other hand, spleen cells from $\Delta X$ and $\Delta Y$ transgenics show a severe defect in presentation of MCC (Figure $6 B$ ). Although some IL-2 is produced, the levels are low and are measurable only at antigen concentrations ten times higher than those required for cells from WT or Sma transgenics.

The $\Delta X$ and $\Delta Y$ defect is not a general antigen presentation problem, since the same spleen cells present KLH (keyhole limpet hemocyanin) very well to the Thybridoma BDK11.1, specific for KLH in association with $A^{b}$ (Figure 6C; Roenm et al., 1982). T cell-mediated suppression or an IL-2 adsorption artifact are probably not involved either because similar results were obtained with both $T$ cell- 


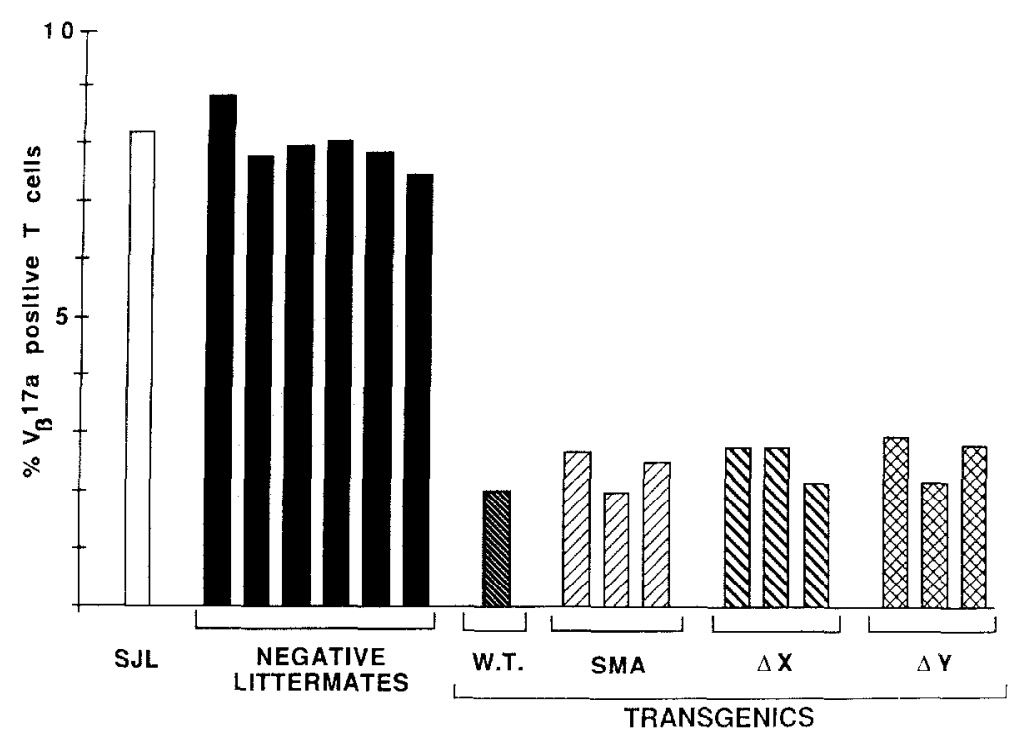

Figure 5. Clonal Deletion of $T$ Cells that Display $V_{\beta} 17 a$ as a Consequence of $E_{\alpha}$ Transgene Expression

Peripheral blood $T$ cells were assayed for the $\mathrm{KJ} 23$ determinant by cytofluorimetry; $\mathrm{KJ} 23$ resides on the $V_{\beta} 17 \mathrm{a}$ variable region of the $T$ cell receptor $\beta$ chain. Colis werc stained with biotinlabeled KJ23 followed by phycoerythrin-avidin, and with FITC-labeled anti-lyt2 and anti-L3T4 mabs. The plotted data derive from two-color flow cytometric analysis and represent the percentage of T cells (FITC-labeled) that are aiso stained by KJ23. The individual animals derive from a double-backcross to SJL from the standard transgenic breeding lines (themselves at the fifth or sixth backcross to B6). Some of the offspring are homozygous for the SJL T cell receptor $\beta$ chain genes $\left(T_{c} R_{\beta}\right)$; the others are heterozygous, carrying one $T_{c} R_{\beta}$ chromosome from $S J L$ and the other from B6. Since B6 mice do not carry $V_{\beta} 17 a$ genetic information, the data were corrected for the heterozygotes by multiplying the measured percentages by two, to compensate for allelic exclusion (Kappler et al., 1987a).
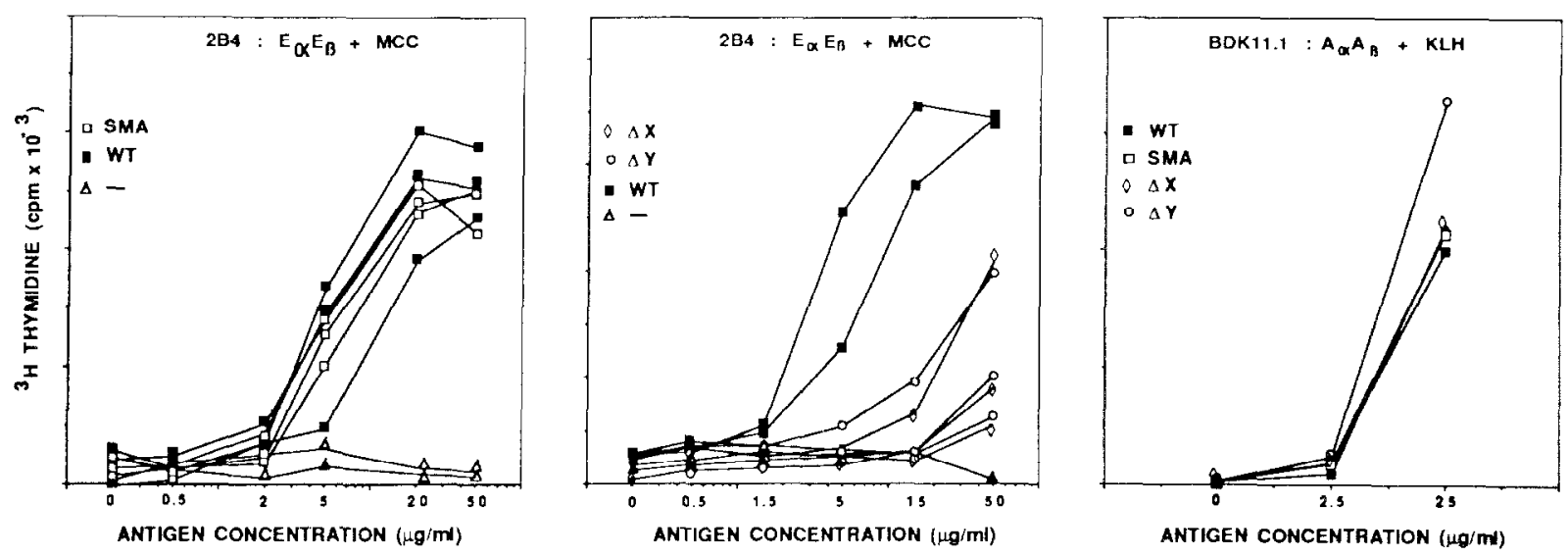

Figure 6. Antigen Presentation to T Hybridomas by Spleen Cells from Transgenic Mice

The 2B4 hybridoma recognizes a peptide from moth cytochrome $c$ (MCC 88-103) in the context of the $E_{\alpha}: E_{\beta}$ complex, while BDK11.1 is specific for keyhole limpet hemacyanin $(K L H)$ presented by $A_{\alpha}: A_{\beta}^{b}$ molecules. The hybridomas were incubated with increasing concentrations of the relevant antigen in the presence of X-irradiated spleen cells from various mice: WT, either $B 10 . A(5 R)$ mice naturally expressing the $E_{\alpha}^{k}: E_{\beta}^{b}$ complex, or WE3225 mice $(\boldsymbol{\square})$; Sma $(\square), \Delta X(\diamond)$ and $\Delta Y(O)$ lransgenics; lransgene-negative lillermates $(\boldsymbol{\Delta})$. IL-2 was detecled using the IL-2-dependent $C T L L$ cell line (see Experimental Procedures). The data represent the incorporation of $\left[{ }^{3} \mathrm{H}\right]$ thymidine by CTLL.

depleted and adherent spleen cells. The $\Delta \mathrm{X}$ and $\Delta \mathrm{Y}$ presentation defect is also seen with lymph node APCs (data not shown).

\section{In Vivo Immune Responses}

B cell-deficient mice show impaired T cell priming, in particular, poor secondary proliferative responses to antigen (for references, see Ron and Sprent, 1987). This defect was first revealed in experiments with mice injected from birth with anti- $\mu$ antibody. The Sma transgenics offer the possibility of verifying these results with animals that have normal $B$ cells but for their lack of $E$ complex expression.

To assay $T$ cell priming, we injected animals subcutaneously with an E-restricted antigen (MCC, or the synthetic copolymer Glu-Lys-Phe [GL $\varphi]$ ), removed cells from the draining lymph nodes 8 days later, and cultured them in vitro with or without antigen. For a good proliferative response, $T$ cells must have a repertoire capable of recognizing antigen in the context of the $E$ molecule and must have been primed efficiently in vivo. The results in Figure $7 A$ are a compilation from several experiments with the E-restricted antigens GL $\varphi$ or MCC. Antigen-driven T cell proliferation, reflected by the stimulation index, is only observed with the wild-type transgenics $E_{\alpha} 16$ and WE32.25, and the range of stimulation indices is similar to that observed for normal $\mathrm{E}^{+}$animals. In contrast, Sma, $\Delta \mathrm{X}$, and $\Delta Y$ transgenics show little or no response to MCC or GL(p, and the range of indices is like that of the control transgene-negative littermates. Proliferation to the purified protein derivative of $M$. tuberculosis was found with 


\section{A. T CELL RESPONSE

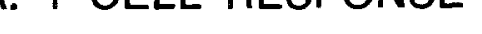

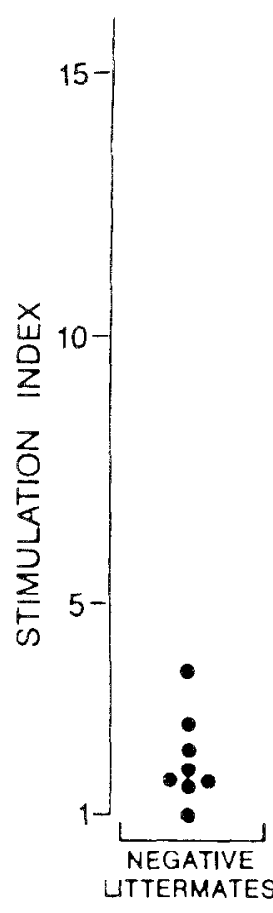

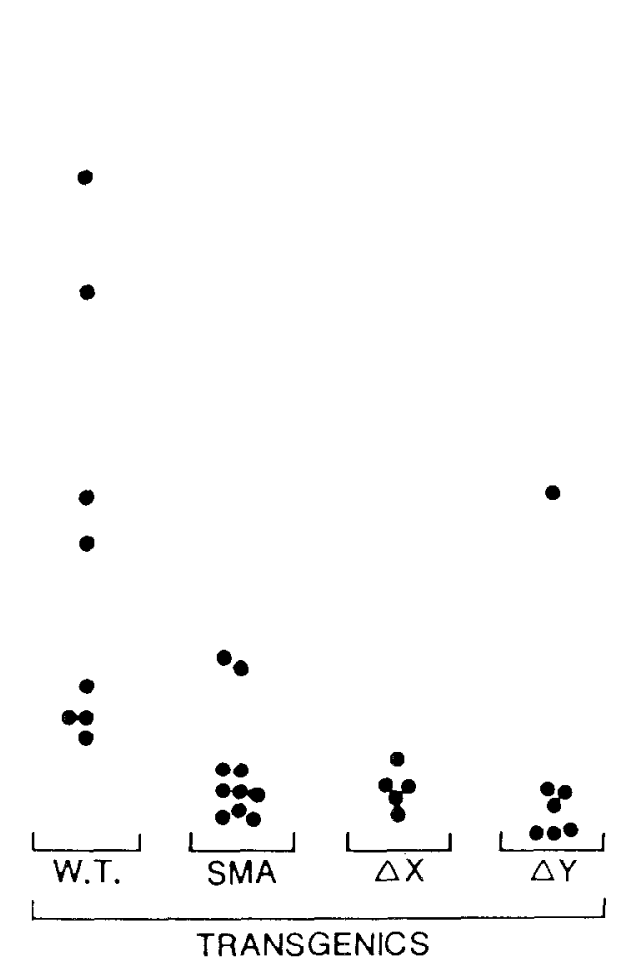

TRANSGENICS

\section{B. ANTIBODY RESPONSE}
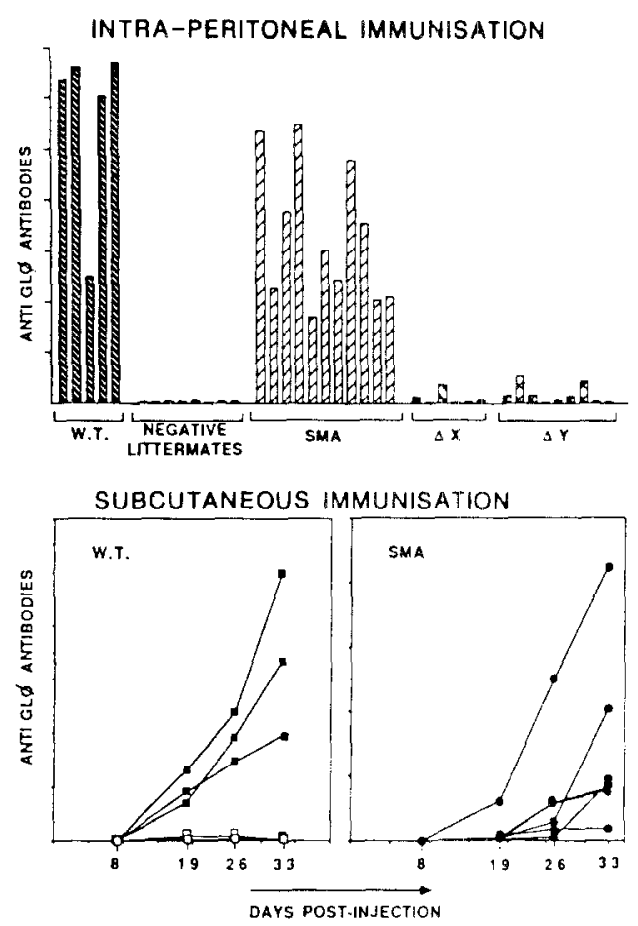

Figure 7. In Vivo Tests of Immune Capacity

(A) T cell priming to E-restricted antigens. Transgenic animals and their transgene-negative littermates were immunized by subcutaneous (footpad) injection of E-restricted antigens (GL $\varphi$ or MCC peptide). Cells form the draining lymph nodes were placed in culture 1 week later in the presence or absence of antigen. Proliferation is measured by [ $\left.{ }^{3} \mathrm{H}\right]$ thymidine incorporation during a $16 \mathrm{hr}$ pulse after 4 days of culture; the stimulation index corresponds to the ratio of incorporation for cells cultured with antigen over incorporation for cells without antigen. Each point represents a single animal. Data are pooled from three different experiments with either GL $\varphi$ or MCC.

(B) Antibody response to E-restricted antigens. Specific anti-GL $\varphi$ antibodies were measured by an ELISA assay after secondary inilraperitoneal immunization (upper panel), or in successive bleedings after a single subcutaneous challenge (lower panel). Plotted values correspond to the average of duplicate samples, expressed in OD units that are normalized by comparison to a laboratory standard anti-GL $\varphi$ antiserum. in the upper panel, each bar represents a different animal, and the results from two independent experiments are pooled. In the lower panel, each curve represents a different animal-either WE32-25 ( $\boldsymbol{\square}$, left), transgene-negative littermates ( $\square$, left and right), or Sma transgenics ( $\bullet$, right).

all animals (data not shown); in this control experiment, $T$ cells are primed by the CFA itself, in an E-unrestricted manner.

In a final set of experiments, we sought to assay the whole spectrum of E-controlled events; an in vivo antibody response should require efficient $T$ cell education, $T$ cell priming, and T-B interactions. Responses were measured after two immunization protocols. First, GL $\varphi$-specific antibodies were titered 7-10 days after a secondary intraperitoneal (ip) injection. The responses of individual animals are depicted in Figure $7 B$, upper panel. Healthy anti-GL $\varphi$ titers are seen with the Sma transgenics, similar (although somewhat lower on average) to those of wildtype transgenics or normal $E_{\alpha}^{+}$animals. The anti-GL $\varphi$ antibodies are of the IgG class in both WT and Sma animals (data not shown). In contrast, $\Delta X$ and $\Delta Y$ mice make essentially no anti-GL $\varphi$ antibody response.

In the second protocol, GL $\varphi$ was administered in a single subcutaneous (sc) injection into the footpad and the animals bled at regular intervals thereafter. It has been hypothesized that the key APCs are different in immune responses that develop in the spleen versus lymph node
(Ron and Sprent, 1987, and references therein). Nevertheless, the anti-GL $\varphi$ responses after sc priming did not differ markedly from those observed after ip priming: little or no response with $\Delta X$ and $\Delta Y$ animals (data not shown), but a significant anti-GL $\varphi$ antibody production with Sma transgenics (Figure 7B, lower panel). With this protocol, however, there is a delayed onset of anti-GL $\varphi$ antibody production (except for one animal). Again, antibodies are essentially of the IgG class (data not shown).

Thus, on the basis of both an in vitro test of antigen presentation and diverse assays of in vivo immunocompetence, both $\Delta X$ and $\Delta Y$ mice show greatly impaired E-restricted immune capabilities. In contrast, Sma mice display many essentially normal features of an E-restricted response.

\section{Discussion}

Compartmentalization of $E_{\alpha}$ Transgene Expression

The results presented here are a good illustration of the point that different cis-acting promoter elements are responsible for the regulation of MHC class II gene tran- 
scription in different cell types (Dorn et al., 1987, and submitted; Widera et al., 1987). We have shown a clear dissociation of expression in thymic cortical versus medullary cells, in B cells versus non-B cells, and in germinal center versus follicular $B$ cells.

Transgenic mice that carry the $\Lambda X$ and $\Delta Y$ mutant genes show striking differences in thymic expression pattern. The deleted segments (the $X$ and $Y$ boxes) are conserved in sequence among all MHC class II gene promoters; additionally, the two boxes are separated by an essentially invariant interval (for references, see Dorn et al., 1987). This implies that they function in concert, most likely by binding factors that interact with each other, under tight stereochemical constraints (see Takahashi et al., 1986). One might then have expected similar phenotypes to result upon deletion of either box; on the contrary, converse patterns of $E_{\alpha}$ expression were observed in thymus sections from $\Delta \mathrm{X}$ and $\Delta \mathrm{Y}$ transgenics. Medullary cells are $\mathrm{E}^{+}$in $\Delta \mathrm{X}$ thymuses, while cortical cells are essentially $E^{-}$. On the other hand, cortical cells are $E^{+}$in $\Delta Y$ thymuses, while almost all cells in the medulla are $\mathrm{E}^{-}$.

Results from the Sma lines demonstrate that the previously noted B-cell control region at $-2 \mathrm{~kb}$ to $-1 \mathrm{~kb}$ (Widera et al., 1987; Dorn et al., submitted) is indeed necessary for $E_{\alpha}$ expression in the vast majority of $B$ cells. Yet, $E_{\alpha}$ transgenes lacking this region ar $\theta$ active in a small subpopulation of B lymphocytes, namely the germinal center B cells. This subpopulation represents a very specific stage in the $B$ differentiation pathway: these are blast cells, actively dividing and undergoing immunoglobulin heavy chain class switching (Kraal et al., 1982). Clearly, these $B$ cells have turned on a different transcriptional program (i.e., new regulatory factors), which allows them to transcribe the $E_{\alpha}$ gene in the absence of the upstream $B$ cell control region. We have not been able to reproduce this "turn on" in vitro: anti-lg antibody, IL-4, LPS, and combinations thereof do not induce $E_{u}$ expression in bulk lymphocyte cultures from Sma transgenics (Figure 3, and data not shown). Thus, simple activation is not enough to induce $E_{\alpha}$ expression in Sma B cells. Although it is possible that we have simply not found the appropriate culture conditions and/or inducers, this result suggests that the micro-environment of the germinal center may be key to the switch in transcription programs.

Besides allowing conclusions about the role of individual promoter elements in different tissues, the set of transgenic lines described here has great potential for studies on the role of class II molecules in various compartments of the immune system. An important point must be underlined, a point crucial for the validity of the immunological analyses. Since only the expression of $E$ complex was manipulated, with A complex expression remaining untouched, our transgenic lines have healthy im. mune systems. Lymphoid organs in the different $E_{\alpha}$ transgenics have a normal structure, and we detect normal frequencies of $B$ cells and of $T$ cell subsets. This point is important because in a number of previously described transgenic lines, gross distortions were observed in the distribution or frequency of immunocompetent cell populations, e.g., in transgenics carrying immunoglobulin,
Thy-1 or T cell receptor genes (Herzenberg et al., 1987; Chen et al., 1987; M. Davis, unpublished data).

\section{Thymic Education}

$\Delta \mathrm{X}$ and $\Delta \mathrm{Y}$ transgenics, with their converse expression of $E_{\alpha}$ in the thymus, are clearly of interest for studying the imprinting of $\mathrm{MHC}$ restriction and $\mathrm{MHC}$ tolerance on the $T$ cell repertoire. Several issues remain unresolved: Are these biases acquired together or separately? Which thymocyte population is the target of selection? Which thymic stromal cell(s) is involved? The consensus view is that class II molecules on the cortical epithelium dictate MHC restriction, and that $\mathrm{MHC}$ tolerance is imparted by macrophages and interdigitating cells of the medulla. T cells would first be positively selected on the epithelium for having some affinity to self-MHC, and then counterselected in the medulla to eliminate cells with too high an affinity for self-MHC (to remove autoreactive cells; see Marrack and Kappler, 1987).

Following this line of reasoning, one might have expected $T$ cells from $\Delta X$ animals to be tolerant of $E$ molecules yet not restricted by them. Indeed, the phenotype of the peripheral immune system in these animals is consistent with this hypothesis: tolerance of the $E$ molecules (no MLR reactivity and low $V_{\beta} 17 a$ expression), but no E-restricted responses (at the level of $T$ cell proliferation or antibody production). Unfortunately, the antigen presentation defect revealed by the in vivo presentation assay clouds this interpretation (Figure 6), since the inability of $\Delta X$ animals to make $E$-dependent responses could be due to poor antigen presentation rather than to faulty E-restriction. It will be necessary to perform more sophisticated transfer experiments before making solid conclusions about the MHC restriction status of $\Delta \mathrm{X} T$ cells.

On the other hand, the thymus in $\Delta Y$ animals, with a normal $\mathrm{E}^{+}$cortex but an essentially $\mathrm{E}^{-}$medulla, should impart MHC restriction but not tolerance. This is clearly not the case. $T$ cells from $\triangle Y$ animals do not react in MLRs to $E_{\alpha}: E_{\beta}$ stimuli, and there is a low frequency of $V_{\beta} 17 a$ usage (Table 2; Figure 5). In addition, because animal and spleen weights for $\Delta Y$ transgenics and their negative littermates are similar, it does not appear that nontolerant $T$ cells emigrating from a $\Delta Y$ thymus into an $\mathrm{E}^{+}$periphery respond to $E$ as an alloantigen (as in a graft-versus-host reaction). Thus, $\Delta \mathrm{Y}$ mice are tolerant of $\mathrm{E}$ molecules.

In theory, this tolerance could be imprinted in the thymus and/or periphery, but preliminary results suggest that it is at least partially thymus acquired. Low $V_{\beta} 17 \mathrm{a}$ frequencies are detected in mature thymocytes, prior to exposure to peripheral E complexes (data not shown). Two types of thymic cells could be involved in this thymic tolerance induction: the $\mathrm{E}^{+}$cortical epithelial network, or the very few $\mathrm{E}^{+}$meduliary cells. The first hypothesis directly contradicts data from reconstitution experiments with deoxyguanosine-treated thymic rudiments (Ready et al., 1984; Lo and Sprent, 1986; von Boehmer and Hafen, 1986). One possible source of this discrepancy is that the deoxyguanosine-treated explant developing in a nude mouse may not fully regenerate a thymic structure, and is thus not competent to impart tolerance; the $\mathrm{E}^{+}$cortex in 
a $\Delta Y$ mouse has a normal structure, and might have this capacity. Such an explanation is supported by embryo transplantation experiments in which thymic epithelial grafts induced tolerance to donor MHC (Ohki et al., 1987). The second possibility, namely that $E$ tolerance in $\Delta Y$ mice is induced by the rare $\mathrm{E}^{+}$medullary IDCs, is more consistent with currently popular hypotheses. This interpretation implies that a very few medullary cells suffice for tolerance induction, and if correct, urges that our data be considered in the interpretation of results from radiation chimeras.

\section{Antigen Presentation and T-B Cell Interactions}

The restriction of antigen presentation by $\mathrm{MHC}$ class II molecules is the second major issue addressed by these studies. Two distinct defects in E-restricted presentation have been observed with our transgenic lines. The first anomaly is that manifested by $\Delta X$ and $\Delta Y$ spleen or lymph node cells, which present only inefficiently a short antigenic peptide to the 2B4 hybridoma. The faulty presenter is probably an adherent cell, since the defect in presentation is also apparent when adherent cells are used as APCs. That B cells do not play much of a role in the in vitro stimulation of T hybridomas by spleen APCs is supported by the efficient E-restricted antigen presentation shown by Sma spleen cells, and is in accord with previous observations (Cowing and Chapdelaine, 1983; Krieger et al., 1985). It was not possible to identify more explicitly the affected cell from our immunohistological analyses, since there are clearly $\mathrm{E}^{+}$IDCs in the T cell areas of both $\Delta \mathrm{X}$ and $\Delta Y$ lymphoid organs and $E^{+}$macrophages in at least the $\Delta X$ spleen. Our current hypothesis is that presentation to $2 \mathrm{~B} 4$ involves a subpopulation of IDCs that we cannot yet distinguish. Unfortunately, we cannot evaluate with certainty the impact of this defect on E-restricted immune function in vivo; doubts concerning the restriction status of $\Delta X$ and $\Delta Y T$ cells prevent a firm conclusion. However, if one assumes that $T$ cells are $E$-restricted in at least one of these two lines, the inference must be that the defective antigen presentation pathway is of major importance: $\Delta X$ and $\triangle Y$ show essentially no $T$ cell proliferation and no antibody responses to MCC or GL $\varphi$.

The second antigen presentation defect is that observed with Sma transgenics. In the absence of $E$ complex on most B cells, little or no T cell priming takes place after subcutaneous immunization, as measured by the standard $T$ cell proliferation assay. Furthermore, we have found that efficient $T$ cell priming can be reconstituted in Sma transgenics by prior administration of $\mathrm{E}^{+} \mathrm{B}$ cells from $E_{\alpha} 16$ (Y. R., unpublished data). The lack of $T$ cell proliferative responses is in full agreement with similar data from mice rendered $B$ cell-deficient by anti- $\mu$ treatment from birth (Ron et al., 1981; Hayglass et al., 1986; Ron and Sprent, 1987). Nevertheless, we are placed in what appears, at least superficially, to be a paradoxical situation: Sma transgenics make good E-controlled antibody responses in the absence of helper $T$ cell priming. Two points must be considered in resolving this apparent dilemma. First, the $T$ cell proliferation assay may be insensitive, showing a high threshold before a measurable response. Indeed, it has previously been reported that significant (although much reduced) priming of helper activity can be detected in anti- $\mu$ treated mice by employing a sensitive in vivo assay (Ron and Sprent, 1987). The other point is that the priming APCs in Sma transgenics (limited to $M(p s$ and/or IDCs) may differentially activate distinct subsets of T lymphocytes, one of which could be geared toward B cell help and the other toward proliferative responses. This kind of partitioning is known to exist among L3T4 $^{+}$T cell clones (Kim et al., 1985; Mosmann et al., 1986), and there is also precedent for differential activation of T cell functions by different APCs (Ramila et al., 1985).

Another apparent paradox is how the $\mathrm{E}^{-} \mathrm{B}$ cells in Sma transgenic mice obtain $T$ cell help for E-restricted responses. Numerous studies have shown $T-B$ interactions to be MHC restricted (Katz et al., 1975; Sprent, 1978; Kappler et al., 1982), although the generality of this phenomenon has been questioned (for review, see Singer and Hodes, 1983). Possibly, anti-GL $\varphi$ antibody production is due to the $\mathrm{Lyb5}^{+}$subpopulation of $\mathrm{B}$ cells, whose activation can bypass MHC restriction (Singer and Hodes, 1983). Alternatively, considering the delayed kinetics of the anti-GL $\psi$ response in Sma transgenics, one could hypothesize that help is inefficient at first, but improves as GL $\varphi$-specific, $E^{-}$follicular B cells move into the germinal centers and become $\mathrm{E}^{+}$.

In conclusion, we have created a set of transgenic mice of significant interest. Aside from clearly illustrating the role of different promoter elements in regulating $E_{\alpha}$ expression in different cell-types, experiments with these mice shed light on several important immunological questions. More elaborate experiments are required to fully exploit the potential of these animals, but the results reported here already offer tantalizing suggestions that accepted dogmas may have to be modified.

\section{Experimental Procedures}

\section{Mice}

Transgenic lines derive from $\mathrm{C} 57 \mathrm{BI} / 6 \times$ SJL F2 embryos injected with various $\mathrm{E}_{\alpha}$ gene fragments, as described (Le Meur et al., 1985). The transgene positives were propagated as heterozygotes by repeated backcrossing to C57BL/6J inbred mice. In each generation, positivo animals were identified by Southern blotting of tail DNA (Le Meur et al., 1985).

The $E_{\alpha} 16$ lire carries the wild-type $E_{\alpha}^{k}$ gene (Le Meur et al., 1985). The "pseudo-wild-type" transgenic line WE32.25 bears essentially the same $E_{\alpha}^{k} D N A$ fragment as $E_{\alpha} 16$; only a few bases have been changed due to the transformation of restriction enzyme sites (Dorn et al., 1987). These minor modifications appear to be innocuous because the $E_{a}$ gene carried in WE32.25 behaves exactly like the wild-type $E_{\alpha}^{k}$ gene. The creation of and transcriptional analysis of transgenic lines bearing mutant $E_{\alpha}^{k}$ genes has been described elsewhere: WE $\Delta \times 21.16$ and WEAY301.54 (Dorn et al., 1987) Sma58 and Sma 65 (Dorn et al., submitted).

The animals used in various experiments spanned several generations: $E_{\alpha} 16$, generations VIII or IX (corresponding to the seventh or eighth backcross to B6); WE32.25, generations III to V; WEAX21.16 and WE $\triangle Y 301.54$, generations III to VI; and Sma58 and Sma65, generations IV to VI. Both Sma58 and Sma65 individuals were used in the experiments reported here, and they behaved identically. $E_{\alpha} 16$ and WE32.25 animals were also used interchangeably as "wild-type" transgenics, unless otherwise specified. 


\section{Antigens}

The antigens used in this study were: MCC, the 81-103 or 88-103 peptides from hornworm moth cytochrome $c$ (kind gifts from $Y$. Patterson and $H$. Grey, respectively); GLO, the synthetic copolymer Glu-Lys-Phe (a kind gift from H. McDevitt); OVA, chicken ovalbumin (Sigma); and PPD, purified protein derivative from M. tuberculosis (Wellcome, UK).

\section{Immunohistology}

The mAbs used in this study were: 14.4 .4 (anti- $E^{k}$; Ozato et al., 1980); $2 A 2$ (anti-A ${ }^{b}$; Beck et al., 1986); $3 G 2$ (anti-A ${ }^{b}$; Beck et al., 1986), ERTR1 (anti-E; van Vliet et al., 1984); ER-TR4 (thymic cortical epithelial cells; van Vliet et al., 1984); ER-TR5 (thymic medullary epithelial cells; van Vliet et al., 1984); ER-TR6 (thymic interdigitating reticular cells; van Vliet et al., 1984); RA3.6B2 (B lymphocytes, B220; Coffman, 1982); and F4/80 (macrophages; Austin and Gordon, 1981).

Lymphoid organs were removed from 6 to 10 week old mice, collectively embedded in Tissue-tek on specimen stubbs, frozen on solid $\mathrm{CO}_{2}$, and stored at $-35^{\circ} \mathrm{C}$. Six micron frozen sections were cut on a Leitz cryostat and collected on microscope slides precoated with a solution containing $0.1 \%$ gelatin and $0.01 \%$ chromium-potassium sulfate. The tissue was gently fixed by dipping the slide for $1 \mathrm{sec}$ in acetone. Slides were stored at $-20^{\circ} \mathrm{C}$ for no longer than 1 week before use. Before incubation with various antibodies, sections were soaked in PBS supplemented with $0.5 \%$ horse serum (HS) and $0.01 \%$ Tween 20 (PBSHS Tw) for $30 \mathrm{~min}$ to remove the embedding medium. Sodium azide was omitted from the rinsing buffers because this preservative was found to reduce the enzyme activity of horse radish peroxidase. Next, sections were overlaid with $100 \mu \mathrm{l}$ of the first stage antibody and incubated for $30 \mathrm{~min}$ at room temperature; during incubation, they were kept in moist chambers to prevent air drying. After rinsing in PBS-HS$T w$, sections were incubated with $50 \mu \mathrm{l}$ anti-immunoglobulin horseradish peroxidase conjugate (Dako, $\mathrm{P} 162$ ) for $30 \mathrm{~min}$ at room temperature. After rinsing in PBS for $30 \mathrm{~min}$, the conjugate was visualized by incubation of the sections in diaminobenzidene (DAB; Sigma Chemical, St. Louis, MO) according to Graham and Karnovsky (1966). The sections were then briefly washed, postfixed in 1\% glutaraldehyde in PBS, dehydrated, and coverslipped. Photographs were recorded on Ifford Pan F films with Zeiss plan-apo objectives; the contrast of the image was enhanced with a Schott interference filter at $490 \mathrm{~nm}$ (Schott, IL490).

For fluorescence studies, frozen sections were incubated with 100 $\mu$ l of purified FITC-labeled monoclonal anti-E (clone $14.4 .4 ; 10 \mu \mathrm{g} / \mathrm{ml}$ diluted in PBS-HS) and with undiluted culture supernatant of clones ERTR4, ERTR5 or ER-TR6, and F4/80. Binding of these rat mAbs was detected with $100 \mu \mathrm{l}$ Texas Red (TxR)-labeled Ig fraction of goat anti-rat Ig antiserum (Southern Biotechnology Assoc., diluted at $20 \mu \mathrm{g} / \mathrm{ml}$ in PBS-HS). Stained and washed slides were fixed in 1\% paraformaldehyde in PBS and mounted in glycerol/PBS (9:1) containing $1 \mathrm{mg}$ phenylene-diamine/ml, to prevent fading of the fluorochromes (Johnson and Nogueira Aranjo, 1981). Micrographs were recorded with a Leitz Orthoplan, equipped with a Leitz Ploemopak 2 illumination system, a $100 \mathrm{~W}$ HBO mercury lamp, a Leitz Vario orthomat camera and a 25x PL APO (25/1.4 Oel Phaco) with 12 (Leitz) filter combination for evaluation of FITC, and N2 filter combination for evaluation of Texas Red. Micrographs were recorded on 400 ASA Kodacolor films.

\section{Flow Cytometry}

Assays of $E_{\alpha}: E_{\beta}$ surface expression by staining cell suspensions with fluorescent reagents and visualizing them on an ODAM ATC 3000 flow cytometer were performed as previously described (Le Meur et al., 1985). Cell populations were analyzed and gated for size by forward small angle light scatter as well as by direct size estimate from impedance measurement, both amplified on linear scales. Fluorescence signals were amplified on logarithmic scales. To detect A complexes, we used mAb 3G2, affinity purified on Protein $A$ (Beck et al., 1986); the anti-E reagent 14.4.4S was used as a first step either in purified, unconjugated form, or after conjugation to biotin (Ozato et al., 1980). Second step reagents were either an FITC-labeled goat $F\left(a b^{\prime}\right) 2$ anti-mouse $\lg \mathrm{G}(\mathrm{Fc})$ (Jackson Immunoresearch Labs) or phycoerythrin-avidin (Biomeda). In some experiments, cell populations were counterstained with FITC-conjugated goat anti-mouse IgM (Southern Biotechnology Associates) or peanut agglutinin.

The frequency of $T$ cells expressing the $V_{\beta} 17 a T$ cell receptor variable region was determined as prevlously described (Kappler et al., 1987a). Briefly, peripheral blood $T$ cells were enriched by red blood cell lysis in Gey's solution (Gey and Gey, 1936) and nylon wool column fractionation. They were then stained with biotinylated KJ23a mAb (specific for a $V_{\beta} 17 a$ encoded determinant; Kappler et al., 1987b) and phycoerythrinavidin, along with FITC-labeled mAbs GK1.5 and 2.43 (anti-L3T4 and anti-Lyt2, respectively; Dialynas et al., 1983; Sarmiento et al., 1982). Two-color cytofluorimetric analysis allowed a determination of the percentage of mature cells (Lyt2 or L3T4 positive) that were also $\mathrm{KJ}_{23}{ }^{+}$. The experimental animals derived from a doublebackcross of the transgene-positive individuals to $\mathrm{SJL}$ mice. Some animals still carried a $\mathrm{T}$ cell receptor chromosome that does not code for the $V_{\beta} 17 a$ region from the $B 6$ parent. These heterozygotes were identifled by reactivity of a subset of $T$ cells with $\mathrm{KJ} 16$, a mAb specific for the $V_{\beta} 8$ family. (The $V_{\beta} 8$ region is missing from the SJL genome.) With such heterozygotes, the measured $\mathrm{KJ}_{2} 3 \mathrm{a}^{+}$percentages were multiplied by two to correct for allelic exclusion.

To test for the induction of la expression during B cell activation, splenocytes were cultured for $24 \mathrm{hr}$ in RPMI, 10\% FCS, $50 \mu \mathrm{M}$ 2-mercaptoethanol supplemented with affinity purified rabbit anti-mouse $\mathrm{lg}$ $(2 \mu \mathrm{g} / \mathrm{ml})$ or with mouse ||$-4$. The latter was added as a culture supernatant from a HeLa cell line transfected with an expressible IL-4 CDNA clone; the supernatant (a kind gift from Drs. Bergstedt and Severinson) was added to a $1 \%$ final concentration.

\section{Immunoprecipitation and Two-Dimensional Polyacrylamide} Gel Electrophoresis

Splenocytes from $B 10 . A(5 R)$ mice or from transgenic animals were labeled by culturing them in the presence of ${ }^{35} S$ Imethionine. $E_{\alpha}^{k}: E_{B}^{b}$ molecules were precipitated from splenocyte NP-40 extracts using the mAb 14.4.4. Immunoprecipitates were electrophoresed on two-dimensional (NEPHGE/SDS) gels and visualized by autoradiography. All procedures are essentially as detailed by Jones (1980).

\section{Mixed Lymphocyte Reactions}

Responder cells were lymph node celis treated with complement in the presence of the anti-B cell mAb J11d (Bruce et al., 1981). Stimulator cells were total spleen cells X-irradiated. Three types of mice were employed as a source of stimulators. Two littermates from generation VIII of the $E_{\alpha} 16$ line, one positive for the $E_{\alpha}^{k}$ transgene and one negative, were used to calculate the stimulation index; the differential response to these two stimulators signifies recognition of the $E_{\alpha}^{k}: E_{b}^{b}$ complex. The third stimulator, from an $\mathrm{H}-2$ incompatible mouse (BALB/c), served as a positive control of responsiveness. Cultures were set up in triplicate in a 96 well plate in RPMI, 10\% FCS, $50 \mu \mathrm{M}$ 2-mercaptoethanol, $2 \mathrm{mM}$ glutamine, $50 \mu \mathrm{M}$ indomethacine, with $2 \times 10^{5}$ responder and $4 \times 10^{5}$ stimulator cells [ ${ }^{3} \mathrm{H}$ ]thymidine was added in the last $12 \mathrm{hr}$ of a $96 \mathrm{hr}$ culture period, and incorporated radioactivity was measured by liquid scintillation counting after automatic harvesting (PHD Harvester).

\section{T Cell Proliferation Assays}

Mice were primed with GL $\varphi$ or MCC in CFA in the hind footpad or the tail base. After 8 days, cell suspensions were prepared from draining lymph nodes. In 96 well plates, $4 \times 10^{5}$ cells per well were cultured in triplicate for $96 \mathrm{hr}$ in RPMI $50 \mu \mathrm{M}$ 2-mercaptoethanol supplemented with $1 \%$ fresh mouse serum and various concentrations of the relevant antigens. MCC was usually used at $100 \mu \mathrm{g} / \mathrm{ml}, \mathrm{GL} \varphi$ at $150 \mu \mathrm{g} / \mathrm{ml}$, and PPD at $50 \mu \mathrm{g} / \mathrm{ml}$. Cultures were harvested on day 4 , with a $\left[{ }^{3} \mathrm{H}\right]$ thymidine pulse in the last $16 \mathrm{hr}$. The stimulation index is defined as the ratio (cpm in cultures with antigen per $\mathrm{cpm}$ in cultures lacking antigen).

\section{T Hybridoma Stimulation}

The T cell hybridoma 2B4 (Schwartz et al., 1985, a kind gift from $R$. Schwartz) recognizes the moth cytochrome $C$ peptide $81-103$ in the context of the $E_{a}^{k}: E_{B}^{b}$ molecule; BK11.1 reacts to KLH in association with $A_{\alpha}^{b}: A_{\beta}^{b}$ complexes (Roehm et al., 1982). Antigen presentation was tested by coculturing $5 \times 10^{4}$ hybridoma cells per well with variable numbers (usually $2.5 \times 10^{5}$ ) of X-irradiated splenocytes and various quantities of antigen, as specified for each experiment. Cultures were set up in $200 \mu \mathrm{l}$ of RPMI, $10 \% \mathrm{FCS}, 50 \mu \mathrm{M} 2$-mercaptoethanol. Fifty microliters of supernatant were removed after $24 \mathrm{hr}$ and tested for IL-2, using the IL-2 dependent T cell line CTLL ( 5000 cells/well). These cells were starved of IL-2 for 6-8 hr, then added to the superrialants to be 
tested. Cultures were incubated for $16 \mathrm{hr}$ in the presence of $\left[{ }^{3} \mathrm{H}\right]$ thymidine, harvested, and the incorporated radioactivity determined by liquid scintillation counting

\section{Antibody Responses}

Intraperitoneal priming: mice were injected ip with $25 \mu \mathrm{g}$ of $\mathrm{GL} \varphi$ in CFA, and were boosted 3 weeks later with $20 \mu \mathrm{g}$ of GL $\varphi$ in phosphatebuffered saline. They were bled 7 days later, and GL $\phi$-specific antibodies were detected in an ELISA assay as described (Le Meur et al. 1985). The developing reagent in most experiments was a polyvalent antibody (goat anti-mouse lgG $+\lg M[H+L]$ coupled to alkaline phosphatase [Jackson Immunoresearch Labs]). The data presented in this paper regroup mice from several independent experiments, and are normalized to arbitrary units by comparison to a laboratory standard anti-GI_p serum

Subcutaneous priming: mice were given a single injection of $\mathrm{GL}_{\varphi} \varphi$ in CFA $(25 \mu \mathrm{g})$ in one footpad. They were bled at regular intervals thereafter, and sera tested for anti-GL $\varphi$ antibodies as described above.

\section{Acknowledgments}

Special thanks go to $G$. Lang for maintaining and typing the transgenic linos and to B. Schuhbaur for tissue sections. We would also like to acknowledge $\mathrm{C}$. Waltzinger for operating the cytofluorimeter and $\mathrm{P}$. Gerber for excellent assistance. We are grateful to Drs. S. Bergstedt, H. Grey, H. McDevitt, Y. Patterson, M. Pierres, R. Schwartz, E. Severinson, and J. Sprent for gifts of materials and/or useful advice. This work was supported by grants from the A. D. Williams Foundation and the National Institutes of Health (GM38774) to J. M., from Medigon (\#900505-122) to W. v. E., from the National Institutes of Health (PO1Al22295 and Al18755) to P. M. and J. K., and from the ARC and the CNRS (ATP "Recepteurs de I'Immunité") and the Juvenile Diabetes Foundation to D. M. and C. B. Y. R. was supported by an INSERM short-term fellowship.

The costs of publication of this article were defrayed in part by the payment of page charges. This article must therefore be hereby marked "advertisement" in accordance with 18 U.S.C. Section 1734 solely to indicate this fact.

Received December 21, 1987; revised February 12, 1988.

\section{References}

Austin, J., and Gordon, S. (1981). F4/80 a monoclonal antibody directed specifically against the mouse macrophage. Eur. J. Immunol. 11 805-815.

Beck, B. N., Buerstedde, J. M., Krco, C. J., Nislon, A. E., Chase, C. G., and McKean, D. J. (1986). Characterization of cell lines expressing mutant $1-A^{b}$ and $I-A^{k}$ molecules allows the definition of distinct serologic epitopes on $A_{\alpha}$ and $A_{\beta}$ polypeptides. J. Immunol. 136, 2953-2961.

Benoist, C., Gerlinger, P., Le Meur, M., and Mathis, D. (1986). Transgenic mice: "new wave" immunogenetics. Immurul. Today $7,138-141$. Bruce, J., Symington, F. W., McKearn, T. J., and Sprent, J. (1981). A monocional antibody discriminating between subsets of $T$ and $B$ cells. J. Immunol. 127, 2496-2501.

Chen, S., Botteri, F., van Der Putten, H., Landel, C. P., and Evans, G. A. (1987). A lymphoproliferative abnormality associated with inappropriate expression of the Thy-1 antigen in transgenic mice. Gell 51, $7-19$.

Chesnut, R. W. and Grey, H. M. (1981). Studies on the capacity of B cells to serve as antigen-presenting cells. J. Immunol. 126, 1075-1079. Coffman, R. L. (1982). Surface antigen expression and immunoglobulin gene rearrangement during mouse pre-B cell development. Immunoi. Rev. 69, 5-23.

Cowing, C., and Chapdelaine, J. M. (1983). T cells discriminate between la antigens expressed on allogeneic accessory cells and $B$ cells: a potential function for carbohydrate side chains on la molecules. Proc. Natl. Acad. USA 86, 6000-6004.

Dialynas, D., Quan, Z., Wall, K., Pierres, A., Quintans, J., Loken, M., Pierres, M., and Fitch, F. (1983). Characterization of the murine T cell surface molecule, designated L3T4, identified by monoclonal antibody GK-1.5: similarity of L3T4 to the human Leu3/T4 moleculle and the possible involvement of L3T4 in class II MHC antigen reactivity. J. Immunol. 137, 2445-2451.

Dorn, A., Durand, B., Marfing, C., Le Meur, M., Benoist, C., and Mathis, $D$. (1987). Conserved major histocompatibility complex class II boxes $-X$ and $Y$-are transcriptional control elements and specifically bind nuclear proteins. Proc. Nati. Acad. Sci. USA 84, 6249-6253.

Fink, P. J., and Bevan, M. J. (1979). H-2 antigens of the thymus determine lymphocyte specificity. J. Exp. Med. 148, 776-790.

Gey, G., and Gey, M. (1936). The maintenance of human normal and tumor cclls in continuous culturc. I. Preliminary report: cultivation of mesoblastic tumors and normal tissue and notes on methods of cultivation. Amer. J. Cancer 27, 45-58.

Graham, T. V., and Karnovski, M. J. (1966). The early stages of absorption of injected horse radish peroxidase in the proximal tubules of mouse kidney: ultrastructural cytochemistry by a new technique. J. Histochem. Cytochem. 14, 291-297.

Haskins, K., Hannum, C., White, J., Roehm, N., Kubo, R., Kappler, J., and Marrack, P. (1984). The major histocompatibility complex-restricted antigen receptor on T cells. VI. An antibody to a receptor allotype. J. Exp. Med. 160, 452-471.

Hayglass, K. T., Naides, S. J., Scott, C. F., Benacerraf, B., and ManSun, S. (1986). T cell development in B cell-deficient mice. J. Immunol. $136,823-829$.

Herzenberg, L. A., Stall, A. M., Braun, J., Weaver, D., Baltimore, D., Herzenberg, L. A., and Grosschedl, R. (1987). Depletion of the predominant B-cell population in immunoglobulin $\mu$ heavy-chain transgenic mice. Nature 329, 71-76.

Inaba, K. R. M., Steinman, R., Van Voorhis, W. C., and Muramatsu, S. (1983). Dendritic cells are critical accessory cells for thymus-dependent antibody responses in mouse and in man. Proc. Natl. Acad. Sci. USA 80, 6041-6045.

Johnson, G. D., and de C. Nogueira Aranjo, G. M. (1981). A simple method of reducing the fading of immunofluorescence during microscopy. J. Immunol. Meth. 43, 349-350.

Jones, P. P. (1980). Analysis of radiolabeled lymphocyte proteins by one- and two-dimensional polyacrylamide gel electrophoresis. In Selected Methods of Cellular Immunology, B. Mischell and S. Shiigi, eds. (San Francisco: W. H. Freeman and Co.), pp. 398-440.

Jordan, R. K., Robinson, J. H., Hopkinson, N. A., House, K. C., and Bentley, A. L. (1985). Thymic epithelium and the induction of transplantation tolerance in nude mice. Nature $314,454-456$.

Kappler, J., White, J., Wegmann, D., Mustain, E., and Marrack, P. (1982). Antigen presentation by la-positive $B$ cell hybridomas to $\mathrm{H}-2$ restricted T cell hybridomas. Proc. Natl. Acad. Sci. USA 79, 36043608 .

Kappler, J. W., Roehm, N., and Marrack, P. (1987a). T cell tolerance by clonal elimination in the thymus. Cell $49,273-280$.

Kappler, J. W., Wade, T., White, J., Kushnir, E., Blackman, M., Bill, J., Roehm, N., and Marrack, P. (1987b). A T cell receptor $V_{\beta}$ segment that imparts reactivity to a class II major histocompatibility complex product. Cell 49, 263-271.

Kast, W. M., Voordouw, A. C., Leupers, T., Visser, J. W. M., and Melief, C. J. M. (1987). Thymic immune response genc fusion in radiation chimeras reconstituted with purified hemopoietic stem cells. Eur. J. Immunol. 17, 471-475.

Katz, D. H., Graves, M., Dorf, M. E., Dimuzio, H., and Benacerraf, B. (1975). Cells interactions between histoincompatible $T$ and $B$ lymphocytes. VII. Cooperative responses between lymphocytes are controlled by genes in the I region of the H-2 complex. J. Exp. Med. 141, 263-274.

Kawamura, H., and Berzofsky, J. A. (1986). Enhancement of antigenic protency in vitro and immunogenicity in vivo by coupling the antigen to anti-immunoglobulin. J. Immunol. 136, 58-65.

Kim, J., Woods, A., Becker Dunn, E., and Bottomly, K. (1985). Distinct functional phenotypes of cloned la-restricted helper $T$ cells. $J_{\text {N }}$ Exp. Med. 162, 188-201.

Kraal, G., Weissman, I. L., and Butcher, E. C. (1982). Germinal centre 
$B$ cells: antigen specificity and changes in heavy chain class expression. Nature 298, 377-380.

Kraal, G., Hardy, R. R., Gallatin, W. M., Weissman, I. L., and Butcher D. (1986). Antigen-induced changes in B cell subsets in lymph nodes: analysis by dual fluorescence flow cytofluorimetry. Eur. J. Immunol. 16 829-834.

Krieger, J. 1., Grammer, S. F., Grey, H. M., and Chesnut, R. W. (1985) Antigen presentation by splenic $B$ cells: resting $B$ cells are ineffective, whereas activated $B$ cells are effective accessory cells for $T$ cell responses. J. Immunol. 135, 2937-2945.

Kruisbeek, A. M., Davis, M. L., Matis, L. A., and Longo, D. L. (1984). The self-recognition specificity expressed by $T$ cells from nude mice. Absence of detectable la-restricted $T$ cells in nude mice that do exhibit self-K/D restricted T cell responses. J. Exp. Med. 160, 839-851.

Kruisbeek, A. M., Mond, J. J., Fowlkes, B. J., Carmen, J. A., Bridges, S., and Longo, D. L. (1985). Absence of the Lyt-2 ${ }^{-}$, L3T4 ${ }^{+}$lineage of $T$ cells in mice treated neonatally with anti-l-A correlates with absence of intrathymic I-A-bearing antigen-presenting cell function. J. Exp. Med. 161, 1029-1047.

Lanzavecchia, A. (1985). Antigen-specific interaction between $T$ and $B$ cells. Nature 314, 537-539.

Le Meur, M., Gerlinger, P., Benoist, C., and Mathis, D. (1985) Correcting an immune-response deficiency by creating $E_{a}$ gene transgenic mice. Nature 316, 38-42.

Lo, D., and Sprent, J. (1986). Identify of cells that imprint H-2-restricted T-cell specificity in the thymus. Nature 319, 672-675.

Longo, D. L., and Davis, M. L. (1983). Early appearance of donor-type antigen presenting cells in the thymuses of 1,200 rad radiation-induced bone marrow chimeras correlates with self-recognition of donor I region gene products. J. Immunol. 130, 2525-2530.

Longo, D. L., and Schwartz, R. H. (1980). T-cell specificity for $\mathrm{H}-2$ and Ir-gene phenotype correlates with the phenotype of thymic antigenpresenting cells. Nature $287,44-46$.

Longo, D. L., Kruisbeek, A. M., Davis, M. L., and Matis, L. A. (1985) Bone marrow-derived thymic antigen-presenting cells determine selfrecognition of la-restricted T lymphocytes. Proc. Natl. Acad. Sci. USA 82, 5900-5904.

MacLennan, I. C. M., and Gray, D. (1986). Antigen-driven selection of virgin and memory $B$ cells. Immunol. Rev. 91, 61-86.

Malynn, B. A., and Wortis, H. H. (1984). Role of antigen-specific B cells in the induction of SRBC-specific T cell proliferation. J. Immunol. 132 2253-2257.

Marrack, P., and Kappler, J. (1987). The T cell receptor. Science 238, 1073-1079.

Mathis, D., Benoist, C., Williams, V., Kanter, M., and McDevitt, $H$. (1983). Several mechanisms can account for defective $E_{\alpha}$ gene expression in different mouse haplotypes. Proc. Natl. Acad. Sci. USA 80 273-277.

Mosmann, T. R., Cherwinski, H., Bond, M. W., Giedlin, M. A., and Coffman, R. L. (1986). Two types of murine helper T cell clone. J. Immunol 136, 2348-2357.

Onki, H., Martin, C., Corbel, C., Coltey, M., and Le Douarin, N. M (1987). Tolerance induced by thymic epithelial grafts in birds. Science 237, 1032-1035.

Ozato, K., Mayer, N., and Sachs, D. (1980). Hybridoma cell lines secreting monoclonal antibodies to mouse $\mathrm{H}-2$ and la antigens. J. Immunol $107,481-488$.

Peck, A., Klein, J., and Wigzell, H. (1980). The mouse-primed lymphocyte typing test: dissociation of $\mathrm{T}$ lymphocyte-stimulating determinants and antibody-defined specificities of the E-associated la antigens. I. Immunol. 125, 1078-1087.

Pinkert, C., Widera, G., Cowing, C., Heber-Katz, E., Palmiter, R. D., Flavell, R. A., and Brinster, R. L. (1985). Tissue-specitic, inducible and functional expression of the $E_{\alpha}^{\alpha} \mathrm{MHC}$ class II gene in transgenic mice. EMBO J. 4, 2225-2230.

Ramila, G., Sklenar, I., Kennedy, M., Sunshine, G. H., and Erb, P. (1985). Evaluation of accessory cell heterogeneity II. Failure of den- dritic cells to activate antigen-specific $T$ helper cells to soluble antgens. Eur. J. Immunol. 15, 189-192.

Ready, A. R., Jenkinson, E. J., Kingston, R., and Owen, J. J. T. (1984) Successful transplantation across major histocompatibility barrier of deoxyguanosine-treated embryonic thymus expressing class If anigens. Nature 310, 231-233.

Rock, K. L., Benacerraf, B., and Abbas, A. K. (1981). Antigen presentation by hapten-specific $B$ lymphocytes. I. Fole of surface immunoglobulin receptors. J. Exp. Med. 160, 1102-1113.

Roehm, N. W. Marrack, P., and Kappler, J. W. (1982). Antigen-specific $\mathrm{H}-2$ restricted helper T cell hybridomas. J. Exp. Med. 156, 191-204.

Ron, $Y_{-1}$ and Sprent, J. (1387). T cell priming in vivo: a major role for $B$ cells in presenting antigen to $T$ cells in lymph nodes. J. Immunol. 138, 2848-2856.

Ron, Y., DeBaetselier, P., Gordon, J., Feldman, M., and Segal, S (1981). Defective induction of antigen-reactive proliferating $T$ cells in $B$ cell deprived mice. Eur. J. Immunol. 11, 964-972

Ron, Y., Lo, D., and Sprent, J. (1986). T cell specificity in twiceirradiated $F_{1} \rightarrow$ parent bone marrow chimeras: failure to detect a role for immigrant marrow-derived cells in imprinting intrathymic $\mathrm{H}-2$ restriction. J. Immunol. 137, 1764-1771.

Sarmiento, M., Dialynas, D., Lanki, D., Wall, K., Lorber, M., Loken M. and Fitch, F. (1982). Cloned T lymphocyles and monoclonal antibodies as probes for cell surface molecules active in $\mathrm{T}$ cell-mediated cytolysis. Immunol. Rev. 68, 135-169.

Schwartz, R. (1984). The role of gene products of the MHC in T cell activation and cellular interactions. In Fundamental Immunology $W$ Paul, ed. (New York: Raven Press), pp. 379-439.

Schwartz, R. H., Fox, B. S., Fraga, E., Chen, C., and Singh, B. (1985) Ihe T lymphocyte response to cytochrome C. J. Immunol. 135, 25982602.

Singer, A., and Hodes, R. (1983). Mechanisms of T cell-B cell interac tion. Annu. Rev. Immunol. 1, 211-241.

Singer, A., Hathcock, K. S., and Hodes, R. J. (1982). Self-recognition in allogeneic thymus chimeras. Selt-recognition by $T$-helper cells from thymus-engrafted nude mice is restricted to the thymic $\mathrm{H}$-2 haplotype. J. Exp. Med. 155, 339-351.

Sprent, J. (1978). Restricted helper function of $F_{1}$ hybrid T cells positively selected to heterologous erythrocytes in irradiated parental sirain mice. I. Failure to cullałuorale with B cells of the opposite parental strain not associated with active suppression. J. Exp. Med. 147, 1142-1154.

Takahashi, K., Vigneron, M., Matthes, H., Wildeman, A., Zenke, M., and Chambon, P. (1986). Requirement of stereospecific alignments for initiation from the simian virus 10 early promoter. Nature 319, 121-126. Unanue, E. R., and Allen, P. M. (1987). The basis for the immunoregulatory role of macrophages and other accessory cells. Science 236 , 551-557.

van Vliet, E., Melis, M., and van Ewijk, W. (1984). Monoclonal antibodics to stromal coll types of the mouse thymus. Eur. J. Immunol. 14, 524-529.

van Boehmer, H., and Hafen, K. (1986). Minor but not major histocompatibility antigens of thymus epithelium tolerize precursors of cytolytic $T$ cells. Nature $320,626-628$.

Widera, G., Burkly, L. C., Pinkert, C. A., Böttger, E. C., Cowing C., Palmiter, R. D., Brinster, R. L., and Flavell, R. A. (1987). Transgenic mice selectively lacking $\mathrm{MHC}$ class II (1-E) antigen expression on $B$ celis: an in vivo approach to investigate la gene function. Cell 51 , 175-187.

Yamamura, K., Kikutani, H., Folsom, V., Clayton, L. K., Kimoto, M., Akira, S., Kashiwamura, S., Tonegawa, S., and Kishimoto, T. (1985). Functional expression of a microinjected $E_{a}^{d}$ gene in C57BL/6 transgenic mice. Nature 376, 67-69.

Zinkernagel, R. M., Calahan, G. N., Klein, J., and Dennert, G. (1978). Cytotoxic $T$ cells learn specificity for self $\mathrm{H}-2$ during differentiation in the thymus. Nature $271,251-253$. 